\title{
Chromosomal Assignment of Quantitative Trait Loci Influencing Modified Hole Board Behavior in Laboratory Mice using Consomic Strains, with Special Reference to Anxiety-related Behavior and Mouse Chromosome 19
}

\author{
Marijke C. Laarakker · Frauke Ohl • \\ Hein A. van Lith
}

Received: 30 March 2007 / Accepted: 6 December 2007/Published online: 4 January 2008

(C) Springer Science+Business Media, LLC 2007

\begin{abstract}
Male mice from a panel of chromosome substitution strains (CSS, also called consomic strains or lines) - in which a single full-length chromosome from the $\mathrm{A} / \mathrm{J}$ inbred strain has been transferred onto the genetic background of the C57BL/6J inbred strain-and the parental strains were examined in the modified hole board test. This behavioral test allows to assess for a variety of different motivational systems in parallel (i.e. anxiety, risk assessment, exploration, memory, locomotion, and arousal). Such an approach is essential for behavioral characterization since the motivational system of interest is strongly influenced by other behavioral systems. Both univariate and bivariate analyses, as well as a factor analysis, were performed. The $\mathrm{C} 57 \mathrm{BL} / 6 \mathrm{~J}$ and $\mathrm{A} / \mathrm{J}$ mouse parental inbred strains differed in all motivational systems. The chromosome substitution strain survey indicated that nearly all mouse chromosomes (with the exception of chromosome 2) each contain at least one quantitative trait locus (QTL) that is involved in modified hole board behavior. The results agreed well with previous reports of QTLs for anxiety-related behavior using the A/J and C57BL/6J as parental strains. The present study confirmed that mouse chromosomes 5, 8, 10, 15, 18 and 19 likely
\end{abstract}

Edited by Pierre Roubertoux.

M. C. Laarakker $(\bowtie) \cdot$ F. Ohl · H. A. van Lith

Department of Animals, Science \& Society, Division of

Laboratory Animal Science, Faculty of Veterinary Medicine,

Utrecht University, Yalelaan 2, P.O. Box 80166, 3508 TD

Utrecht, The Netherlands

e-mail: m.c.laarakker@uu.nl

M. C. Laarakker · F. Ohl · H. A. van Lith

Rudolf Magnus Institute of Neuroscience, Utrecht,

The Netherlands contain at least one anxiety QTL. There was also evidence for a novel anxiety QTL on the Y chromosome. With respect to anxiety-related avoidance behavior towards an unprotected area, we have special interest for mouse chromosome 19. CSS-19 (C57BL/6J-Chr19 $/ \mathrm{NaJ})$ differed in avoidance behavior from the C57BL/6J, but not in locomotion. Thus pleiotropic contribution of locomotion could be excluded.

Keywords Anxiety · A/J · C57BL/6J ·

Chromosome substitution strain - Consomic strain .

Mice - Modified hole board test - Factor analysis .

Bivariate and univariate analysis

\section{Introduction}

Anxiety and other psychiatric disorders are one of the most common diseases in humans. Kessler et al. (2005) found that about $29 \%$ of the U.S. population had an anxiety disorder sometime during their life. Anxiety is a multidimensional phenomenon presumed to have a complex inheritance, involving the interaction of multiple genes in combination with epigenetic and environmental factors. Family, linkage and twin studies have consistently indicated that genes indeed play a role in the etiology of anxiety disorders; the heritability has been estimated to be 30-50\% (Gordon and Hen 2004). Unfortunately, attempts to find these human genes have been largely unsuccessful. Therefore, animal models of anxiety were developed to facilitate the discovery of the genetic and neurobiological substrates of anxiety and test putative anxiolytic drugs (Ohl 2005).

Over the past decade, methods for genome analysis of animal models have been developed to identify and locate QTLs (Flint et al. 2005). Chromosome substitution strains (CSS, also called consomic strains or lines) (Sansom 2005; 
http://www.informatics.jax.org/mgihome/nomen/strains. shtml\#consomic; http://www.rgd.mcw.edu/nomen/rulesfor-nomen.shtml\#consomic), represents a relatively new strategy and can accelerate the identification and mapping of QTLs. Chromosome substitution strains are produced by transferring a single, full-length chromosome from one inbred strain - the donor strain-onto the genetic background of a second strain-the host strain-by repeated backcrossing (Singer et al. 2004). Because the host and donor strain are genetically very diverse, the consomic panels can be used as a general genetic discovery tool. Therefore, panels of chromosome substitution strains are an advantage to researchers studying the genes affecting developmental, physiological and behavioral processes.

The first complete mouse CSS set, created from A/J and C57BL/6J strains, was produced in 2004 (Singer et al. 2004). The two parental inbred strains from this consomic panel are frequently used in anxiety research (Bouwknecht and Paylor 2002) and they also differ in terms of sensitivity for benzodiazepines (Mathis et al. 1995). Trullas and Skolnick (1993) ranked 16 inbred strains of mice on anxiety-related phenotypes; the A/J and C57BL/6J strains were found to be at opposite ends of the phenotypic spectrum. The A/J strain has been identified as one of the most anxiogenic-like strain across a number of paradigms.

The Division of Laboratory Animal Science, Utrecht University is specifically interested in the identification of genetic factors underlying the development of (pathological) anxiety. Here we report that anxiety-related behavior, when the mice were tested in the modified hole board test (Ohl 2005), differs between two inbred strains of mice $(\mathrm{C} 57 \mathrm{BL} / 6 \mathrm{~J}$ and $\mathrm{A} / \mathrm{J})$, and the use of CSS generated from these two strains to identify chromosomes that harbor QTL that influence anxiety-related behavior. Singer et al. (2004, 2005) already examined this panel of CSS using other ethological tests of anxiety-like behavior (open field and light-dark box). However in contrast to the open field, the light-dark box as well as the elevated plus maze, the modified hole board test is a complex behavioral test for rodents, that allows for the assessment of a variety of different motivational systems in parallel (Ohl et al. 2001; Ohl 2005). Turri et al. (2004) demonstrated that multivariate analysis when compared with univariate analysis, has an increased power to detect QTLs when the genetic effects are correlated. Since the anxiety-related behavioral parameters of the modified hole board were related to each other (Laarakker et al. 2006), we performed both univariate and bivariate statistical analyses. Previous QTL analyses, using $\mathrm{A} / \mathrm{J}$ and $\mathrm{C} 57 \mathrm{BL} / 6 \mathrm{~J}$ as parental strains and different mapping populations, suggest that mouse chromosome 19 plays a significant role in anxiety-related behavior (Gershenfeld and Paul 1997; Gershenfeld et al. 1997; Gill and Boyle 2005; Zhang et al. 2005; Singer et al.
2004, 2005). Therefore this study focused on mouse chromosome 19.

\section{Materials and methods}

Ethical note

The protocols of the experiments were peer-reviewed by the scientific committee of the Department of Animals, Science \& Society, Utrecht University, the Netherlands, and approved by the Animal Experiments Committee of the Academic Biomedical Centre, Utrecht-The Netherlands. The Animal Experiments Committee based its decision on 'De Wet op de Dierproeven' (The Dutch 'Experiments on Animals Act'; 1996) and on the 'Dierproevenbesluit' (The Dutch 'Experiments on Animals Decision'; 1996); both are available online (http://www.vet.uu.nl/nca_nl/legislation or http://www.wetten.overheid.nl/). Further, all animal experiments followed the 'Principles of laboratory animal care' and refer to the Guidelines for the Care and Use of Mammals in Neuroscience and Behavioral Research (National Research Council 2003).

Animals and housing

This study was performed using naive male mice from the following commercially available inbred strains: $\mathrm{A} / \mathrm{J}$ (the donor strain; $n=30$ ), C57BL/6J (the host strain; $n=27$ ), and the complete set of chromosome substitution strains between these parental strains ( $n=6$ per consomic line); The Jackson Laboratory, Bar Harbor, ME, USA. All the strains were sampled on several litters in homogenized environmental conditions; the observed phenotypes were highly stable through litters and generations. The chromosome substitution strains, whose nomenclature is C57BL/6J-Chr\# ${ }^{A} / \mathrm{NaJ}$, are simplified to CSS-\#. For CSS-19 21 extra male mice were tested. We tested more host strain animals when compared with consomic mice (except for CSS-19) to improve power to detect a chromosome that contains a QTL. According to Belknap (2003) a 4.5:1 ratio, or $27 \mathrm{C} 57 \mathrm{BL} / 6 \mathrm{~J}$ host strain animals and 6 animals per consomic strain, is the most efficient for selecting chromosome substitution strains that contain a QTL.

The mice were 4-6 weeks old at arrival, and were housed for 2 weeks (pre-experimental period) for habituation in an animal room of the laboratory animal facility at the Department of Animals, Science \& Society (Utrecht University) before the behavioral testing started. The animal room was sound-attenuated. Relative humidity was kept at a constant level of $50 \%$, the ambient temperature was maintained at $21.0 \pm 2.0^{\circ} \mathrm{C}$ and the ventilation rate was 
15-20 air changes per hour. To reduce stress in the laboratory animal facility, during the whole day $(24 \mathrm{~h})$ radiosound $(60 \pm 3 \mathrm{~dB})$ was provided. In addition conversational radio-sound (e.g. talkshows) may accustom the animal to the human voice. Behavioral testing (modified hole board test; see below) was carried out in the same room. All mice were housed individually directly after arrival in enriched, wire topped Macrolon ${ }^{\circledR}$ Type II L (prolonged) cages (size: $365 \times 207 \times 140 \mathrm{~mm}$, floor area $530 \mathrm{~cm}^{2}$; Techniplast, Milan, Italy). Enrichment, besides standard bedding material, included a shelter, a tissue $\left(\right.$ Kleenex $^{\circledR}$ : Kimberly-Clark Professional BV, Ede, The Netherlands) and a small amount (less than a hand full) of paper shreds (EnviroDri ${ }^{\circledR}$ : Technilab-BMI BV, Someren, The Netherlands). Drinking water and standard laboratory food pellets (Rat and Mouse Breeder and Grower, Special Diet Services, Essex, England) were provided ad libitum. The light:dark cycle was reversed (white light: 1900-0700, maximal 150 lux; red light: 0700-1900, maximal 5 lux).

During the habituation period all mice were handled at least three times per week for a few minutes by the person who performed the behavioral testing (MC Laarakker), this included picking up the animal at the tail base and placing it on the hand or arm, and restraining it by hand for a few seconds at random times of the day.

\section{Modified hole board testing}

The behavioral testing was performed using the modified hole board test (Fig. 1). This 5-min test combines the

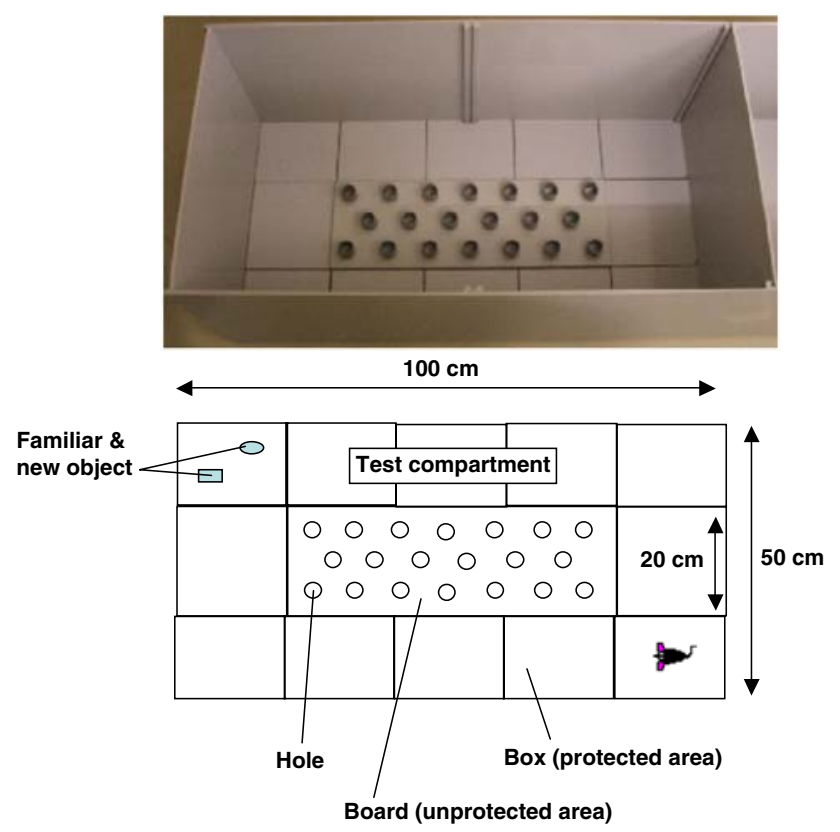

Fig. 1 Overview of the test set-up of the modified hole board features of an open field and a hole board. It allows for testing a variety of motivational systems in parallel (Ohl 2003). The modified hole board basically consists of an opaque gray polyvinylchloride $($ PVC) box $(100 \times 50 \times$ $50 \mathrm{~cm}$, length $\times$ width $\times$ height $)$ which consists of two areas, one protected area-the box-which is surrounded by the protective walls of the set-up, and an unprotected area-the board. Black lines divide the box into 10 rectangles $(20 \times 15 \mathrm{~cm}$, length $\times$ width $)$ and 2 squares $(20 \times$ $20 \mathrm{~cm}$, length $\times$ width $)$. The board $(60 \times 20 \times 0.5 \mathrm{~cm}$, length $\times$ width $\times$ height) is placed in the center of the box, and contains 20 PVC cylinders $(3 \times 3 \mathrm{~cm}$, diameter $\times$ height), positioned across the board in three intended rows. The board is lit with an additional red light lamp $(80 \mathrm{~W})$, such that the board is illuminated with approximately 35 lux, whereas the box is only illuminated with 1-3 lux. The familiar and an unfamiliar object (either a die or a screw nut, depending on what was used as familiar object) are placed in one corner of the box of the modified hole board set-up; this is done in a way that both have the same distance to the wall and that the mouse can still pass along freely.

Behavioral testing was performed between 1000 and 1400 (i.e. during the activity phase of the animals) under red-light conditions; all behavioral tests were videotaped (for raw data storage) from above the box. The behavior was scored by hand using the program Observer 4.1 (Noldus, Wageningen, The Netherlands). The test set-up was cleaned with water and a damp towel between each mouse. Several parameters (Table 1) for anxiety-related behavior, risk assessment, (undirected and directed) exploration, memory, locomotion, arousal and other behavior (e.g. urination) were measured/calculated.

\section{Statistical analyses}

All statistical analyses were carried out according to Petrie and Watson (1995) and/or Quinn and Keough (2002), using a $\operatorname{SPSS}^{\circledR}$ for Windows (version 12.0.1) computer program (SPSS Inc., IL, USA). Two-sided, exact (i.e. for the nonparametric tests) probabilities were estimated throughout. Continuous data (latency, percentage of time, and average duration of the behavioral parameters) were summarized (both in tables and in figures) as means with standard error of the mean (SEM), whereas discrete data on the ordinal scale (total number of the behavioral parameters) were presented in tables as medians with the interquartile range and in figures as box plots (also known as box-and-whisker plots). Box plots show median values with interquartile range, highest and lowest non-outlying values (i.e. values up to 1.5 box lengths from the upper or lower edge of the box). In the figures with box plots (mild) outliers (i.e. cases 
Table 1 Behavioral parameters measured in the modified hole board

\begin{tabular}{|c|c|c|}
\hline Behavioral dimension & Behavioral parameter & Description of the mouse behavior \\
\hline Anxiety & $\begin{array}{l}\text { Total number of board entries } \\
\text { Latency until the first board entry } \\
\text { Percentage of time on the board } \\
\text { Average duration of a board entry }\end{array}$ & Mouse on the board \\
\hline Risk assessment & $\begin{array}{l}\text { Total number of risk assessments } \\
\text { Latency until the first risk assessment }\end{array}$ & Stretched body posture, including hind-paws \\
\hline \multirow[t]{3}{*}{ Undirected exploration } & $\begin{array}{l}\text { Total number of rearings in the box } \\
\text { Latency until the first rearing in the box }\end{array}$ & Rearing on hind-paws in the box \\
\hline & $\begin{array}{l}\text { Total number of rearings on the board } \\
\text { Latency until the first rearing on the board }\end{array}$ & Rearing on hind-paws on the board \\
\hline & $\begin{array}{l}\text { Total number of hole explorations } \\
\text { Latency until the first hole exploration }\end{array}$ & Exploration of a cylinder (hole) on the board \\
\hline \multirow[t]{2}{*}{ Directed exploration } & $\begin{array}{l}\text { Total number of holes visited } \\
\text { Latency until the first hole visited }\end{array}$ & Nose-poking into a cylinder (hole) on the board \\
\hline & $\begin{array}{l}\text { Total number of unfamiliar object explorations } \\
\text { Latency until the first unfamiliar object exploration } \\
\text { Percentage of time being busy with unfamiliar object explorations } \\
\text { Average duration of an unfamiliar object exploration }\end{array}$ & Exploration of the unfamiliar (new) object \\
\hline Memory & $\begin{array}{l}\text { Total number of familiar object explorations } \\
\text { Latency until the first familiar object exploration } \\
\text { Percentage of time being busy with familiar object exploration } \\
\text { Average duration of a familiar object exploration }\end{array}$ & Exploration of the familiar object \\
\hline Locomotion & $\begin{array}{l}\text { Total number of line crossings } \\
\text { Latency until the first line crossing }\end{array}$ & Line crossing with all its paws in the box \\
\hline \multirow[t]{2}{*}{ Arousal } & $\begin{array}{l}\text { Total number of groomings } \\
\text { Latency until the first grooming } \\
\text { Percentage of time being busy with grooming } \\
\text { Average duration of a grooming }\end{array}$ & Self-grooming \\
\hline & $\begin{array}{l}\text { Total number of boli } \\
\text { Latency until the first bolus is produced }\end{array}$ & Defecation \\
\hline \multirow[t]{2}{*}{ Other behavior } & $\begin{array}{l}\text { Number of times the mouse is in the box } \\
\text { Percentage of time in the box } \\
\text { Average duration of a stay in the box }\end{array}$ & Mouse is in the box \\
\hline & $\begin{array}{l}\text { Total number of urinations } \\
\text { Latency until the first time urine is produced }\end{array}$ & Urination \\
\hline
\end{tabular}

with values between 1.5 and 3 box lengths from the upper or lower edge of the box) and extreme cases (i.e. cases with values more than 3 box lengths from the upper or lower edge of the box) are also indicated. Latency of the behavioral parameters is a time to an event parameter and therefore it was also analyzed as survival data; the results were then plotted as Kaplan-Meier curves. The Kolmogorov-Smirnov one sample test was used to check Gaussianity of the continuous data. Group (=strain) analyses using the Kolmogorov-Smirnov test revealed a nonparametric distribution of several continuous parameters for some strains.
Significant differences in the normally distributed continuous data between $\mathrm{C} 57 \mathrm{BL} / 6 \mathrm{~J}$ and $\mathrm{A} / \mathrm{J}$ or each consomic strain was calculated using the unpaired Student's $t$ test (univariate analysis) or Hotelling's $T^{2}$ test (bivariate analysis). The unpaired Student's $t$-tests were performed using pooled (for equal variances) or separate (for unequal variances) variance estimates. Homoscedasticity was tested using the Levene's test, which is a powerful and robust test based on the $F$ statistic (Lim and Loh 1996). For the unpaired Student's $t$-test with separate variance estimates, SPSS $^{\circledR}$ uses the Welch-Satterthwaite correction. The significance of differences for the ordinal data (=total number 
of the behavioral parameters) as well as the non-normally distributed continuous behavioral data were calculated using the Mann-Whitney $U$ test. The Kaplan-Meier plots for latency of the behavioral parameters were compared using the Log-Rank test. Between behavioral parameters Spearman's coefficients of rank correlation $\left(R_{\mathrm{s}}\right)$ were calculated; significance was assessed by a two-tailed test based on the $t$ statistic.

In addition, data were also analyzed by factor analysis using a principal components solution with orthogonal rotation (varimax) of the factor matrix. This method ensures that the extracted factors are independent of one other and should, therefore, reflect separate processes. The varimax algorithm was chosen, because this algorithm attempts to minimize the number of variables that have high loadings (see hereafter) on a factor. This should enhance the interpretability of the factors. The sampling adequacy was measured with the Kaiser-Meyer-Olkin measure (should be greater than 0.5). The Bartlett's test of sphericity was used for testing whether the correlation was appropriate for factor analysis. Factor pattern matrices were identified using a combination of the Kaiser criterion (factors must have eigenvalues $\geq 1$ ) and the Scree test (on a simple line plot, the point of inflection of a plot of the eigenvalues from largest to smallest). The factor loading of each behavioral item indicates how well that item correlates with the factor; thus a loading of \pm 1.0 indicates a perfect (positive/negative) correlation, whereas a loading of less then 0.6 would suggest that the item is rather weakly linked to the factor. In the next step, via regression, factor scores were calculated for each mouse. The extracted, orthogonal factors were compared by the unpaired Student's $t$ test (normally distributed data) or the MannWhitney $U$ test (non-normally distributed data). A one-way analysis of variance with strain as main factor was carried out for each extracted, orthogonal factor across all 20 consomic strains and the host strain. $R^{2}$, the sum of squares between strains divided by the total sum of squares, gives an estimate of the heritability of these factors $\left(h^{2}\right)$, or the proportion of the trait variance due to additive genetic influences (narrow sense heritability) (Belknap 2003).

Recently we suggested, for behavioral genetic experiments using chromosome substitution strains, a limited type of sequential design-the two-stage approach (Laarakker et al. 2006). Briefly, we propose to start the behavioral tests with $27 \mathrm{C} 57 \mathrm{BL} / 6 \mathrm{~J}$ host strain animals and 6 animals per consomic strain. If the $P$ value $<0.05$ for the host versus consomic mice comparison, then it makes sense to test extra animals $(n=21)$ of the appropriate consomic strains. To take into account the greater probability of a Type I error (=erroneously conclude the presence of a significant strain difference) due to the multiple strain comparisons (i.e. host strain versus donor strain or consomic lines), the level of significance for the Student's $t$-tests, Hotelling's $T^{2}$ tests, the Mann-Whitney $U$ tests, and Log-Rank tests was pre-set at $P<0.004$ (as suggested by Belknap 2003). By adjusting $\alpha$ to 0.004 and performing a two-stage approach, a reduction in the number of animals used in these experiments can be obtained (Laarakker et al. 2006).

However, it is well recognized that when one tests multiple hypotheses, all bearing on a single issue (e.g. a behavioral dimension), a more stringent criterion should be used for statistical significance. We approached this problem by calculating for each behavioral dimension separate socalled Dunn-Šidák corrections $\left(\alpha=1-[1-0.004]^{1 / \gamma}\right.$; $\gamma=$ number of parameters per behavioral dimension). We did not use a highly conservative overall Bonferroni correction $(\alpha=0.004 / 1,171 \approx 0.000003)$, because of the large numbers of tests $(1,171)$. This implies that for the comparisons (i.e. for the behavioral measures) with 27 mice of the C57BL/6J host strain versus 6 mice per chromosome substitution strain a $1-[1-0.004]^{1 / \gamma} \leq P<1-[1-0.05]^{1 / \gamma}$ means suggestive evidence for a chromosome harboring a QTL, whereas $P<1-[1-0.004]^{1 / \gamma}$ means significant evidence for a QTL on a chromosome (Belknap 2003). For the extracted, orthogonal factors $0.004 \leq P<0.05$ and $P$ $<0.004$ means suggestive and significant evidence, respectively. Table 2 gives an overview of the (corrected) thresholds used in the multiple strain comparisons.

Calculating numerous correlations also increases the risk of a Type I error. To avoid this, the level of statistical significance of Spearman correlation coefficients were adjusted by using also the Dunn-Šidák method $(\alpha=1-[1$ $-0.05]^{1 / 35} \approx 0.001464 ; 35=$ total number of behavioral parameters). Again we did not use the highly conservative overall Bonferroni correction $(\alpha=0.05 / 595 \approx 0.000084)$, because of the large numbers of correlations (595). In all other cases (i.e. the Kolmogorov-Smirnov one sample test, Levene's test and the Bartlett's test of sphericity), the probability of a Type I error $<0.05$ was taken as the criterion of significance.

\section{Results}

\section{Associations}

For individual mice (i.e. consomic, host and donor strain mice; $n=204$ ) we studied the association between the behavioral parameters of the modified hole board. Table 3 summarizes the calculated coefficients of Spearman's rank correlation. In this table the behavioral parameters are sorted by motivational system. As would be expected for measures within a behavioral test apparatus, there were many (in total 159) significant correlations. 
Table 2 Overview of the (corrected) thresholds for the multiple strain comparisons

\begin{tabular}{lllll}
\hline $\begin{array}{l}\text { Behavioral dimension/ } \\
\text { factor analysis }\end{array}$ & $\begin{array}{l}\text { C57BL/6J }(n=27) \\
\text { versus A/J }(n=30)\end{array}$ & $\begin{array}{l}\text { C57BL/6J }(n=27) \text { versus consomic lines }(n=6) \\
\text { Evidence that a specific chromosome harbors a QTL }\end{array}$ & $\begin{array}{l}\text { C57BL/6J }(n=27) \text { versus } \\
\text { CSS-19 }(n=27)\end{array}$ \\
\cline { 2 - 4 } & Significant difference & Suggestive & Significant & Significant difference \\
\hline Anxiety & $P<0.001002$ & $0.001002 \leq P<0.012741$ & $P<0.001002$ & $P<0.001002$ \\
Risk assessment & $P<0.002002$ & $0.002002 \leq P<0.025321$ & $P<0.002002$ & $P<0.002002$ \\
Undirected exploration & $P<0.000668$ & $0.000668 \leq P<0.008512$ & $P<0.000668$ & $P<0.000668$ \\
Directed exploration & $P<0.000668$ & $0.000668 \leq P<0.008512$ & $P<0.000668$ & $P<0.000668$ \\
Memory & $P<0.001002$ & $0.001002 \leq P<0.012741$ & $P<0.001002$ & $P<0.001002$ \\
Locomotion & $P<0.002002$ & $0.002002 \leq P<0.025321$ & $P<0.002002$ & $P<0.002002$ \\
Arousal & $P<0.000668$ & $0.000668 \leq P<0.008512$ & $P<0.000668$ & $P<0.000668$ \\
Other behavior & $P<0.000801$ & $0.000801 \leq P<0.010206$ & $P<0.000801$ & $P<0.000801$ \\
Factor analysis & $P<0.004$ & $0.004 \leq P<0.05$ & $P<0.004$ & $P<0.004$
\end{tabular}

Parental strain analyses

Mice from the strains $\mathrm{A} / \mathrm{J}$ and $\mathrm{C} 57 \mathrm{BL} / 6 \mathrm{~J}$ were used as donor and host strains for the consomic panel, respectively. The results obtained for the parental strains with the modified hole board are summarized in Fig. 2 (anxiety), and Tables 4 (anxiety) and 5 (risk assessment, undirected exploration, directed exploration, memory, locomotion, arousal, and other behavior). From these tables and figure it is clear that the $\mathrm{A} / \mathrm{J}$ and $\mathrm{C} 57 \mathrm{BL} / 6 \mathrm{~J}$ inbred strains are contrasting: the strains differ in all behavioral dimensions. Highly significant differences between the two parental strains were found for anxiety-related avoidance behavior towards an unprotected area; indicated by the total number of board entries and latency until the first board entry (Table 4, Fig. 2). These results corroborates earlier work (Laarakker et al. 2006). In contrast, there was no significant difference in percentage of time spent on the board and average duration of a board entry (Table 4).

Anxiety-related behavior may significantly be confounded by the overall activity of an animal. The mouse may either avoid a certain area, because it is anxious to explore it or because it is not active enough to reach it. The number of line crossings and the latency until the first line crossing in the box indicates the level of overall activity in the modified hole board test. There were marked strain differences as to locomotor activity: $\mathrm{C} 57 \mathrm{BL} / 6 \mathrm{~J}$ when compared with $\mathrm{A} / \mathrm{J}$ mice are more active (Table 5; total number of line crossings).

Furthermore, mice of the A/J strain showed significantly more risk assessments (total number) than the C57BL/6J mice, and the strains differ also significantly in undirected (i.e. rearing, exploration of the holes) as well as in directed exploratory behavior (exploration of the unfamiliar object): mice of the $\mathrm{A} / \mathrm{J}$ strain had a significantly longer latency until performing the first exploratory behavior and a lower number of explorations and rearings in the box during behavioral testing than C57BL/6J mice (Table 5).
The A/J when compared to the C57BL/6J strain differs for memory performance and arousal behavior. C57BL/6J mice performed significantly more familiar object explorations (total number and latency) when compared with $\mathrm{A} / \mathrm{J}$ mice. The percentage of time being busy with grooming and the average duration of grooming was significantly higher for the A/J strain than for the C57BL/6J strain. In contrast, there was no difference in the number of boli and the latency until the first bolus was produced. C57BL/6J mice stay more frequently and longer in the box than $A / J$ mice (Table 5).

Within the same behavioral dimension some of the parameters are related to each other (see the boxes in Table 3). For example the parameters total number of board entries, latency until the first board entry, percentage of time spent on the board, and average duration of a board entry are significantly associated (Table 3). Therefore-i.e. for the significantly associated parameters within the same behavioral dimension - a multivariate method, such as the Hotelling's $T^{2}$ test, may be used. However, several assumptions are necessary for proper application of the Hotelling's $T^{2}$ test. One of the assumptions is that dependent variables should have a multivariate normal distribution. Because total number is a discrete variable, the joint distribution can never be multivariate normal. To take the total number parameters into account we performed bivariate analyses with latency and average duration as the dependent variables (the parameter average duration is based on the parameters percentage of time and total number). In addition we also performed bivariate analyses with the dependent variables latency and percentage of time. These additional bivariate analyses also resulted in significant parental strain differences for anxiety-related behavior and arousal (Tables 4 and 5). The obtained parental strain differences prompted the investigation into the chromosomal location of the QTLs involved by testing a set of chromosome substitution strains between the $\mathrm{A} / \mathrm{J}$ and $\mathrm{C} 57 \mathrm{BL} / 6 \mathrm{~J}$ strains. 
Table 3 Associations (Spearman's $R_{\mathrm{S}}$ ) between behavioral parameters measured in the modified hole board

Behavioral dimension/parameter

$$
\text { Anxiety }
$$

(1)

Anxiety

Total number of board entries (1)

Latency until the first board entry (2)

Percentage of time on the board (3)

Average duration of a board entry (4)

Risk assessment

Total number of risk assessments (5)

Latency until the first risk assessment (6)

Undirected exploration

Total number of rearings in the box (7)

Latency until the first rearing in the box (8)

Total number of rearings on the board (9)

Latency until the first rearing on the board (10)

Total number of hole explorations (11)

Latency until the first hole exploration (12)

Directed exploration

Total number of holes visited (13)

Latency until the first hole visited (14)

Total number of unfamiliar object explorations (15)

Latency until the first unfamiliar object exploration (16)

Percentage of time being busy with unfamiliar object explorations (17)

Average duration of an unfamiliar object exploration (18)

\section{Memory}

Total number of familiar object explorations (19)

Latency until the first familiar object exploration (20)

Percentage of time being busy with familiar object exploration (21)

Average duration of a familiar object exploration (22)

Locomotion

Total number of line crossings (23)

Latency until the first line crossing (24)

Arousal

Total number of groomings (25)

Latency until the first grooming (26)

Percentage of time being busy with grooming (27)

Average duration of a grooming (28)

Total number of boli (29)

Latency until the first bolus is produced (30)

Other behavior

Number of times the mouse is in the box (31)

Percentage of time in the box (32)

Average duration of a stay in the box (33)

Total number of urinations (34)

Latency until the first time urine is produced (35)

\begin{tabular}{|c|c|c|c|c|c|}
\hline- & - & - & - & - & - \\
\hline-0.650 & - & - & - & - & - \\
\hline 0.785 & 0.552 & - & - & - & - \\
\hline 0.448 & -0.398 & 0.836 & - & - & - \\
\hline-0.472 & 0.393 & -0.361 & -0.243 & - & - \\
\hline 0.094 & -0.058 & 0.079 & 0.049 & -0.576 & - \\
\hline 0.418 & -0.441 & 0.244 & 0.160 & -0.508 & 0.137 \\
\hline-0.016 & 0.042 & 0.040 & 0.100 & 0.202 & -0.135 \\
\hline 0.096 & -0.140 & 0.144 & 0.162 & -0.069 & -0.008 \\
\hline-0.090 & 0.134 & -0.139 & -0.162 & 0.069 & 0.003 \\
\hline 0.940 & $-\mathbf{0 . 6 3 0}$ & 0.845 & 0.577 & -0.477 & 0.094 \\
\hline-0.677 & 0.952 & -0.564 & $-\mathbf{0 . 3 7 9}$ & 0.413 & -0.069 \\
\hline 0.154 & -0.220 & 0.214 & 0.207 & -0.080 & 0.040 \\
\hline-0.154 & 0.223 & -0.217 & -0.211 & 0.077 & -0.036 \\
\hline 0.357 & -0.315 & 0.139 & 0.031 & -0.284 & -0.017 \\
\hline-0.342 & 0.371 & -0.303 & -0.266 & 0.462 & -0.109 \\
\hline 0.150 & -0.162 & 0.087 & 0.012 & -0.104 & -0.061 \\
\hline-0.005 & -0.064 & 0.066 & 0.128 & 0.046 & -0.086 \\
\hline 0.238 & -0.182 & 0.042 & -0.069 & -0.186 & -0.033 \\
\hline-0.290 & 0.270 & $-\mathbf{0 . 3 3 7}$ & $-\mathbf{0 . 3 1 3}$ & 0.361 & -0.082 \\
\hline 0.028 & 0.007 & 0.019 & 0.049 & -0.016 & -0.096 \\
\hline-0.117 & 0.112 & 0.020 & 0.184 & 0.099 & -0.070 \\
\hline 0.418 & -0.249 & 0.141 & -0.045 & -0.400 & 0.086 \\
\hline-0.300 & 0.229 & -0.217 & -0.099 & 0.376 & 0.057 \\
\hline-0.013 & -0.051 & 0.062 & 0.118 & 0.045 & 0.028 \\
\hline 0.035 & 0.017 & -0.021 & -0.090 & 0.038 & -0.028 \\
\hline-0.252 & 0.162 & -0.143 & -0.045 & 0.139 & 0.074 \\
\hline-0.135 & 0.128 & -0.055 & -0.011 & 0.056 & 0.105 \\
\hline-0.119 & 0.149 & -0.066 & -0.008 & 0.165 & -0.039 \\
\hline 0.066 & -0.130 & 0.046 & 0.025 & -0.107 & 0.054 \\
\hline 0.842 & -0.587 & 0.588 & 0.265 & -0.458 & 0.080 \\
\hline-0.306 & 0.182 & -0.584 & -0.502 & 0.096 & -0.001 \\
\hline-0.853 & 0.595 & -0.686 & -0.368 & 0.456 & -0.082 \\
\hline 0.011 & 0.048 & -0.035 & -0.020 & 0.147 & -0.131 \\
\hline-0.009 & -0.052 & 0.034 & 0.019 & -0.144 & 0.123 \\
\hline
\end{tabular}


Table 3 continued

Behavioral dimension/parameter Undirected exploration

(7)

Anxiety

Total number of board entries (1)

Latency until the first board entry (2)

Percentage of time on the board (3)

Average duration of a board entry (4)

Risk assessment

Total number of risk assessments (5)

Latency until the first risk assessment (6)

Undirected exploration

Total number of rearings in the box (7)

Latency until the first rearing in the box (8)

Total number of rearings on the board (9)

Latency until the first rearing on the board (10)

Total number of hole explorations (11)

Latency until the first hole exploration (12)

Directed exploration

Total number of holes visited (13)

Latency until the first hole visited (14)

Total number of unfamiliar object explorations (15)

Latency until the first unfamiliar object exploration (16)

Percentage of time being busy with unfamiliar object explorations (17)

Average duration of an unfamiliar object exploration (18)

\section{Memory}

Total number of familiar object explorations (19)

Latency until the first familiar object exploration (20)

Percentage of time being busy with familiar object exploration (21)

Average duration of a familiar object exploration (22)

\section{Locomotion}

Total number of line crossings (23)

Latency until the first line crossing (24)

Arousal

Total number of groomings (25)

Latency until the first grooming (26)

Percentage of time being busy with grooming (27)

Average duration of a grooming (28)

Total number of boli (29)

Latency until the first bolus is produced (30)

Other behavior

Number of times the mouse is in the box (31)

Percentage of time in the box (32)

Average duration of a stay in the box (33)

Total number of urinations (34)

Latency until the first time urine is produced (35)
(8)

(9)

(10)

(11)

(12)

-
-
-
-
-
-

$-0.296$

$-0.067$

0.067

$-0.212$

0.216

$0.402 \quad 0.033$

$-0.493 \quad 0.034$

$0.120 \quad-0.115$

0.110

$-0.120$

0.009

0.513

0.125

0.110

$-$

$-\mathbf{0 . 3 7 2}$

0.167

$-0.087$

0.190

$-0.205$

0.208

0.209

$-0.226$

$-0.391$

0.114

$-0.049$

0.045

$-0.312$

0.283

0.085

0.084

$-0.095$

0.099

0.029

$-0.007$

$-0.273$

0.059

0.122

$-0.121$

$-0.091$

0.120

0.666

$-0.063$

$-0.151$

0.154

0.363

0.130

$-0.270$

$-0.314$

$-\mathbf{0 . 3 3 5}$

0.179

$-0.132$

$-0.074$

$-0.057$

0.051

0.010

$-\mathbf{0 . 2 6}$
0.209

$-0.008$

0.070
-0.026

0.028

$-0.282$

$-0.030$

$-0.413$

$-0.108$

0.052

$-0.054$

$-0.171$

0.217

$\mathbf{- 0 . 3 0 6}$

$-0.163$

0.083

$-0.084$

$-0.106$

0.170

$-0.136$

0.084

0.002

$-0.007$

0.059

0.134

$0.067-0.051$

$-0.010$

0.014

$-0.117$

\begin{tabular}{rrrrrr}
$\mathbf{0 . 5 2 8}$ & -0.067 & -0.020 & 0.024 & $\mathbf{0 . 7 7 2}$ & $-\mathbf{0 . 6 1 4}$ \\
0.177 & 0.046 & -0.168 & 0.167 & $\mathbf{- 0 . 3 6 5}$ & 0.128 \\
$\mathbf{- 0 . 4 6 5}$ & 0.071 & -0.010 & 0.006 & $\mathbf{- 0 . 7 9 8}$ & $\mathbf{0 . 6 1 3}$ \\
0.100 & 0.052 & -0.067 & 0.064 & 0.028 & 0.006 \\
-0.104 & -0.044 & 0.070 & -0.068 & -0.027 & -0.011 \\
\hline
\end{tabular}


Table 3 continued

Behavioral dimension/parameter

Directed exploration

(13) (14)

(14)

(15)

(16)

(17)

(18)

Anxiety

Total number of board entries (1)

Latency until the first board entry (2)

Percentage of time on the board (3)

Average duration of a board entry (4)

Risk assessment

Total number of risk assessments (5)

Latency until the first risk assessment (6)

Undirected exploration

Total number of rearings in the box (7)

Latency until the first rearing in the box (8)

Total number of rearings on the board (9)

Latency until the first rearing on the board (10)

Total number of hole explorations (11)

Latency until the first hole exploration (12)

Directed exploration

Total number of holes visited (13)

Latency until the first hole visited (14)

Total number of unfamiliar object explorations (15)

Latency until the first unfamiliar object exploration (16)

Percentage of time being busy with unfamiliar object explorations (17)

Average duration of an unfamiliar object exploration (18)

Memory

Total number of familiar object explorations (19)

Latency until the first familiar object exploration (20)

Percentage of time being busy with familiar object exploration (21)

Average duration of a familiar object exploration (22)

\section{Locomotion}

Total number of line crossings (23)

Latency until the first line crossing (24)

Arousal

Total number of groomings (25)

Latency until the first grooming (26)

Percentage of time being busy with grooming (27)

Average duration of a grooming (28)

Total number of boli (29)

Latency until the first bolus is produced (30)

\section{Other behavior}

Number of times the mouse is in the box (31)

Percentage of time in the box (32)

Average duration of a stay in the box (33)

Total number of urinations (34)

Latency until the first time urine is produced (35)

$\begin{array}{ll}- & - \\ - & - \\ - & - \\ - & -\end{array}$

$\begin{array}{ll}- & - \\ - & -\end{array}$$$
-
$$$$
-
$$$$
-
$$$$
-
$$$$
-
$$$$
-
$$$$
-0.999
$$$$
-0.059
$$$$
-0.111
$$$$
0.058
$$$$
\begin{array}{ll}
-0.076 \quad 0.075
\end{array}
$$$$
\begin{array}{ll}
-0.026 & 0.024
\end{array}
$$$$
-0.155
$$$$
0.093
$$

0.664

$\begin{array}{rrrrrr}-0.076 & 0.070 & \mathbf{0 . 6 2 8} & -0.211 & \mathbf{0 . 3 0 4} & -0.011 \\ -0.171 & 0.175 & -\mathbf{0 . 2 2 7} & \mathbf{0 . 5 3 2} & -0.055 & -0.004 \\ -0.036 & 0.033 & \mathbf{0 . 2 7 6} & -0.136 & \mathbf{0 . 3 7 8} & 0.206 \\ 0.035 & -0.034 & -0.149 & -0.028 & 0.109 & \mathbf{0 . 3 1 4}\end{array}$

\begin{tabular}{rrrrrr}
-0.051 & 0.052 & $\mathbf{0 . 5 9 3}$ & $\mathbf{- 0 . 2 8 4}$ & 0.158 & -0.151 \\
0.044 & -0.048 & $-\mathbf{0 . 2 4 0}$ & $\mathbf{0 . 4 2 7}$ & 0.031 & 0.137 \\
& & & & & \\
-0.038 & 0.039 & -0.053 & -0.077 & -0.017 & -0.033 \\
0.009 & -0.011 & 0.045 & 0.097 & 0.038 & 0.043 \\
-0.009 & 0.010 & $-\mathbf{0 . 3 2 5}$ & 0.037 & -0.101 & 0.052 \\
0.060 & -0.060 & $-\mathbf{0 . 2 6 1}$ & -0.012 & -0.092 & 0.023 \\
-0.001 & -0.001 & -0.207 & 0.156 & -0.052 & 0.018 \\
0.009 & -0.006 & 0.179 & -0.158 & 0.053 & 0.008 \\
& & & & & \\
0.046 & -0.048 & $\mathbf{0 . 6 6 7}$ & $-\mathbf{0 . 4 4 1}$ & $\mathbf{0 . 2 6 4}$ & -0.119 \\
-0.166 & 0.166 & 0.169 & 0.124 & -0.105 & -0.185 \\
-0.102 & 0.103 & $-\mathbf{0 . 5 8 8}$ & $\mathbf{0 . 4 6 2}$ & $-\mathbf{0 . 2 6 3}$ & 0.070 \\
0.041 & -0.042 & 0.106 & -0.002 & 0.026 & -0.020 \\
-0.049 & 0.051 & -0.103 & -0.004 & -0.021 & 0.023 \\
\hline
\end{tabular}


Table 3 continued

Behavioral dimension/parameter

\section{Memory}

(19)

Anxiety

Total number of board entries (1)

Latency until the first board entry (2)

Percentage of time on the board (3)

Average duration of a board entry (4)

Risk assessment

Total number of risk assessments (5)

Latency until the first risk assessment (6)

Undirected exploration

Total number of rearings in the box (7)

Latency until the first rearing in the box (8)

Total number of rearings on the board (9)

Latency until the first rearing on the board (10)

Total number of hole explorations (11)

Latency until the first hole exploration (12)

Directed exploration

Total number of holes visited (13)

Latency until the first hole visited (14)

Total number of unfamiliar object explorations (15)

Latency until the first unfamiliar object exploration (16)

Percentage of time being busy with unfamiliar object explorations (17)

Average duration of an unfamiliar object exploration (18)

\section{Memory}

Total number of familiar object explorations (19)

Latency until the first familiar object exploration (20)

Percentage of time being busy with familiar object exploration (21)

Average duration of a familiar object exploration (22)

\section{Locomotion}

Total number of line crossings (23)

Latency until the first line crossing (24)

Arousal

Total number of groomings (25)

Latency until the first grooming (26)

Percentage of time being busy with grooming (27)

Average duration of a grooming (28)

Total number of boli (29)

Latency until the first bolus is produced (30)

Other behavior

Number of times the mouse is in the box (31)

Percentage of time in the box (32)

Average duration of a stay in the box (33)

Total number of urinations (34)

Latency until the first time urine is produced (35)



\section{$-$}

$-$
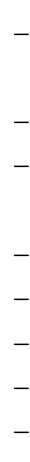

$-$

$-$

$-$

$-$

$-$

$-0.333$

0.498

$-0.420$

$-0.287$

$-0.012$

$-0.015$

(20)

(21)

(22)

Locomotion

(23)

(24)

4)

$\begin{array}{llll}- & & & \\ - & & - & - \\ - & & - & - \\ - & & - & \\ & & - & -\end{array}$

$\begin{array}{lll}- & - & - \\ - & - & -\end{array}$

$-+-$

-

$-$

$-$

$-$

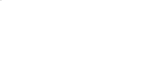

$-$

$-$

$-$

$\mathbf{0 . 2 2 9}$
0.072

0.567

$\begin{array}{llll}\mathbf{0 . 6 8 3} & -\mathbf{0 . 3 1 6} & 0.183 & \mathbf{- 0 . 3 0 0}\end{array}$

$\begin{array}{llll}-0.177 & \mathbf{0 . 3 3 8} & -0.036 & 0.106\end{array}$

$\begin{array}{llll}-0.196 & 0.012 & 0.068 & 0.204\end{array}$

$\begin{array}{ll}0.066 & -0.069\end{array}$

$\begin{array}{ll}\mathbf{0 . 2 3 2} & 0.002\end{array}$

$-0.069$

$-0.300$

0.047

0.156

$-0.109$

0.137

$-\mathbf{0 . 5 2 4}$

$-0.040$

0.078

$-0.097$

0.089

$-0.387$

0.160

0.007

$-0.014$

$-0.038$

$-0.150$

0.072

0.012

0.059

0.107

0.068

$-0.126$

0.548

0.211

$-0.476$

$-0.353$

0.145

0.168

$-0.058$

$\mathbf{- 0 . 2 4 9}$

$-0.163$

$-0.099$

0.562

0.202

0.295

$-\mathbf{0 . 3 4 9}$

0.191

$-0.045$

$-0.027$

$-0.153$

$-0.469$

0.040

$\mathbf{0 . 3 4 4}$

$-0.187$

0.044

0.157

0.136

0.078

$\begin{array}{ll}-0.137 & -0.087\end{array}$


Table 3 continued

Behavioral dimension/parameter Arousal

\section{(25)}

(26)

(27)

(28)

(29)

(30)

Anxiety

Total number of board entries (1)

Latency until the first board entry (2)

Percentage of time on the board (3)

Average duration of a board entry (4)

Risk assessment

Total number of risk assessments (5)

Latency until the first risk assessment (6)

Undirected exploration

Total number of rearings in the box (7)

Latency until the first rearing in the box (8)

Total number of rearings on the board (9)

Latency until the first rearing on the board (10)

Total number of hole explorations (11)

Latency until the first hole exploration (12)

Directed exploration

Total number of holes visited (13)

Latency until the first hole visited (14)

Total number of unfamiliar object explorations (15)

Latency until the first unfamiliar object exploration (16)

Percentage of time being busy with unfamiliar object explorations (17)

Average duration of an unfamiliar object exploration (18)

\section{Memory}

Total number of familiar object explorations (19)

Latency until the first familiar object exploration (20)

Percentage of time being busy with familiar object exploration (21)

Average duration of a familiar object exploration (22)

\section{Locomotion}

Total number of line crossings (23)

Latency until the first line crossing (24)

Arousal

Total number of groomings (25)

Latency until the first grooming (26)

Percentage of time being busy with grooming (27)

Average duration of a grooming (28)

Total number of boli (29)

Latency until the first bolus is produced (30)

Other behavior

Number of times the mouse is in the box (31)

Percentage of time in the box (32)

Average duration of a stay in the box (33)

Total number of urinations (34)

Latency until the first time urine is produced (35)
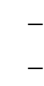

$-$


$\begin{array}{llll}- & & - & - \\ - & & - & - \\ & & & -\end{array}$$$
-
$$

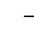

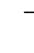$$
-
$$

$$
-
$$$$
-
$$$$
-
$$$$
-
$$$$
-
$$$$
-
$$$$
-
$$

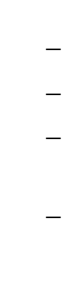

$\begin{array}{lll}- & - & - \\ - & - & -\end{array}$$$
-
$$$$
0.666
$$

0.426

0.011

0.044

0.033

$-0.219$

$-0.070$

0.213

$-0.170$

0.034

0.178

0.172

$\begin{array}{ll}- & - \\ - & - \\ - & - \\ - & -\end{array}$

-
-
-
-

$-$

$-$

$-$

$-$

$-$

$-$

$-$

$-$

$-$

$-$

$-$

-

$-$

$-$

$-$

$-$$$
-
$$

$-$

$-$

$-$

0.096

$\begin{array}{rrrr}\mathbf{- 0 . 3 0 8} & -\mathbf{0 . 2 7 0} & 0.036 & -0.051 \\ 0.183 & 0.106 & 0.147 & -0.096\end{array}$

$\begin{array}{llll}-0.168 & -0.076 & \mathbf{0 . 3 2 1} & \mathbf{- 0 . 3 0 8}\end{array}$

$\begin{array}{llll}0.168 & 0.075 & -\mathbf{0 . 3 1 8} & \mathbf{0 . 3 0 6}\end{array}$ 
Table 3 continued

Behavioral dimension/parameter Other behavior

(31) (32)

(32)

(33)

(34)

(35)

Anxiety

Total number of board entries (1)

Latency until the first board entry (2)

Percentage of time on the board (3)

Average duration of a board entry (4)

Risk assessment

Total number of risk assessments (5)

Latency until the first risk assessment (6)

Undirected exploration

Total number of rearings in the box (7)

Latency until the first rearing in the box (8)

Total number of rearings on the board (9)

Latency until the first rearing on the board (10)

Total number of hole explorations (11)

Latency until the first hole exploration (12)

Directed exploration

Total number of holes visited (13)

Latency until the first hole visited (14)

Total number of unfamiliar object explorations (15)

Latency until the first unfamiliar object exploration (16)

Percentage of time being busy with unfamiliar object explorations (17)

Average duration of an unfamiliar object exploration (18)

\section{Memory}

Total number of familiar object explorations (19)

Latency until the first familiar object exploration (20)

Percentage of time being busy with familiar object exploration (21)

Average duration of a familiar object exploration (22)

\section{Locomotion}

Total number of line crossings (23)

Latency until the first line crossing (24)

Arousal

Total number of groomings (25)

Latency until the first grooming (26)

Percentage of time being busy with grooming (27)

Average duration of a grooming (28)

Total number of boli (29)

Latency until the first bolus is produced (30)

Other behavior

Number of times the mouse is in the box (31)

Percentage of time in the box (32)

Average duration of a stay in the box (33)

Total number of urinations (34)

Latency until the first time urine is produced (35)

\begin{tabular}{|c|c|c|c|c|}
\hline- & - & - & - & - \\
\hline- & - & - & - & - \\
\hline- & - & - & - & - \\
\hline- & - & - & - & - \\
\hline- & - & - & - & - \\
\hline- & - & - & - & - \\
\hline- & - & - & - & - \\
\hline- & - & - & - & - \\
\hline- & - & - & - & - \\
\hline- & - & - & - & - \\
\hline- & - & - & - & - \\
\hline- & - & - & - & - \\
\hline- & - & - & - & - \\
\hline- & - & - & - & - \\
\hline- & - & - & - & - \\
\hline- & - & - & - & - \\
\hline- & - & - & - & - \\
\hline- & - & - & - & - \\
\hline- & - & - & - & - \\
\hline- & - & - & - & - \\
\hline- & - & - & - & - \\
\hline- & - & - & - & - \\
\hline- & - & - & - & - \\
\hline- & - & - & - & - \\
\hline- & - & - & - & - \\
\hline- & - & - & - & - \\
\hline- & - & - & - & - \\
\hline- & - & - & - & - \\
\hline- & - & - & - & - \\
\hline- & - & - & - & - \\
\hline- & - & - & - & - \\
\hline-0.212 & - & - & - & - \\
\hline-0.975 & 0.392 & - & - & - \\
\hline 0.049 & 0.199 & -0.013 & - & - \\
\hline-0.045 & -0.200 & 0.010 & -0.996 & - \\
\hline
\end{tabular}

Association based on 204 animals. Significant $(P<0.001464)$ Spearman's $R_{\mathrm{S}}$ are indicated in bold and bolditalic characters. Associations between the parameters of the same behavioral dimension are indicated by bolditalic and italic characters 




Fig. 2 Kaplan-Meier plots for the parameter latency until the first board entry. Results for male mice from the C57BL/6J host strain $(n=27)$, the A/J donor strain $(n=30)$ and CSS-19 $(n=27)$. For some mice from the CSS-19 and A/J strain latency until the first board entry is said to be censored, indicating that the testing period (300 s) was cut off before the event (=board entry) occurred. We do not know when (or indeed, whether) these mice will experience the event, only that these mice have not done so by the end of the testing period

\section{Chromosome substitution strain survey}

Six males for each strain of the consomic panel were tested for modified hole board behavior. Figure 3 and Table 6 give an overview of the results for anxiety-related behavior. When compared to the host strain $(n=27)$ the consomic panel shows in the univariate analysis significant evidence for an anxiety QTL on chromosome 10. With this type of analysis there is suggestive evidence for anxiety QTLs on chromosomes 5, 8, and Y (Table 6). Bivariate analysis results in two significant (on chromosomes 15 and Y) and three suggestive anxiety QTLs (on chromosomes 10, 18 and 19) (Table 6).

Table 7 summarizes suggestive and significant evidence for a QTL on a chromosome for the remaining parameters of modified hole board behavior. The present chromosome substitution strain survey indicates that nearly all mouse chromosomes (with the exception of chromosomes 2 and 17) each contain at least one QTL that is involved in modified hole board behavior. Further, there is evidence that chromosome 10 contains QTLs for all behavioral dimensions, whereas chromosomes $4,7,8,9,11$, and 14 contain a QTL for only one behavioral dimension. On chromosome 19, besides evidence for an anxiety QTL (Table 6), there is also evidence for a risk assessment and direct exploration QTL (Table 7).

\section{Two-stage approach}

As a proof of principle for the approach (two-phase procedure) that we suggest for behavioral genetic experiments using chromosome substitution strains (i.e. for the consomic survey), 21 additional male CSS-19 animals were tested. We selected CSS-19 because there was no evidence that chromosome 19 contains a locomotion QTL and thus a pleiotropic contribution of locomotion with respect to

Table 4 Anxiety-related behavior in the modified hole board in C57BL/6J, A/J and CSS-19 male mice

\begin{tabular}{|c|c|c|c|c|c|}
\hline \multirow[t]{2}{*}{ Parameter } & \multirow{2}{*}{$\begin{array}{l}\text { C57BL/6J } \\
\text { strain) }\end{array}$} & \multirow{2}{*}{$\begin{array}{l}\mathrm{A} / \mathrm{J} \\
\text { strain) }\end{array}$} & \multirow{2}{*}{$\begin{array}{l}\text { CSS-19 } \\
\text { line) }\end{array}$} & \multicolumn{2}{|l|}{$P$ value } \\
\hline & & & & $\begin{array}{l}\text { Host versus } \\
\text { donor }\end{array}$ & $\begin{array}{l}\text { Host versus } \\
\text { consomic }\end{array}$ \\
\hline \multicolumn{6}{|l|}{ Univariate analysis } \\
\hline $\begin{array}{l}\text { Total number of board entries } \\
\text { (frequency) }\end{array}$ & $11.0(7.0)$ & $1.5(5.0)$ & $5.0(9.0)$ & $* 0.000000^{\mathrm{M}}$ & $* 0.0008900^{\mathrm{M}}$ \\
\hline Latency until the first board entry (s) & $60.6 \pm 5.6$ & $196.7 \pm 20.6$ & $129.6 \pm 17.9$ & $\begin{array}{l}* \mathbf{0 . 0 0 0 0 0 0} 0^{\mathrm{W}} \text { and } \\
* \mathbf{0 . 0 0 0 0}^{\mathrm{L}}\end{array}$ & $\begin{array}{l}* \mathbf{0 . 0 0 0 8 9 8} \mathbf{8}^{\mathrm{W}} \text { and } \\
\quad * \mathbf{0 . 0 0 0 2}^{\mathrm{L}}\end{array}$ \\
\hline $\begin{array}{l}\text { Percentage of time spent on the board } \\
(\%)\end{array}$ & $6.6 \pm 0.9$ & $4.0 \pm 1.1$ & $2.8 \pm 0.7$ & $0.552282^{\mathrm{W}}$ & $0.001437^{\mathrm{S}}$ \\
\hline Average duration of a board entry (s) & $1.6 \pm 0.2$ & $3.6 \pm 0.8$ & $0.8 \pm 0.1$ & $0.023648^{\mathrm{W}}$ & $0.001134^{\mathrm{S}}$ \\
\hline \multicolumn{6}{|l|}{ Bivariate analysis } \\
\hline \multirow{2}{*}{\multicolumn{4}{|c|}{$\begin{array}{l}\text { Latency until the first board entry + percentage of time spent on the board } \\
\text { Latency until the first board entry }+ \text { average duration of a board entry }\end{array}$}} & $* \mathbf{0 . 0 0 0 0 0 0} 0^{\mathrm{H}}$ & $* 0.000445^{\mathrm{H}}$ \\
\hline & & & & $* 0.000000^{\mathrm{H}}$ & $* 0.000425^{\mathrm{H}}$ \\
\hline
\end{tabular}

Values are means \pm SEM (latency, percentage and average duration) or medians with, in parentheses, the interquartile range (frequency) for 27 (C57BL/6J and CSS-19) or 30 (A/J) animals per strain. Note that a $P$ value of 0.000000 (Student's $t$ tests and Mann-Whitney $U$ tests) or 0.0000 (Log-Rank tests) does not mean that it is zero, only that it is less than 0.0000005 or 0.00005 , respectively. Significant $(* P<0.001002)$ strain differences are indicated in bold characters

$\mathrm{H}=$ Hotelling's $T^{2}$ test, $\mathrm{M}=$ Mann-Whitney $U$ test, $\mathrm{S}=$ Student's $t$ test, $\mathrm{W}=$ Student's $t$ test with Welch-Satterthwaite correction, $\mathrm{L}=$ LogRank test 
Table 5 Modified hole board behavior (excluding anxiety) in C57BL/6J, A/J and CSS-19 male mice

\begin{tabular}{|c|c|c|c|c|c|}
\hline \multirow[t]{2}{*}{ Behavioral dimension/parameter } & \multirow{2}{*}{$\begin{array}{l}\text { C57BL/6J } \\
\text { (host } \\
\text { strain) }\end{array}$} & \multirow{2}{*}{$\begin{array}{l}\mathrm{A} / \mathrm{J} \\
\text { (donor } \\
\text { strain) }\end{array}$} & \multirow{2}{*}{$\begin{array}{l}\text { CSS-19 } \\
\text { (consomic } \\
\text { line) }\end{array}$} & \multicolumn{2}{|l|}{$P$ value } \\
\hline & & & & $\begin{array}{l}\text { Host versus } \\
\text { donor }\end{array}$ & $\begin{array}{l}\text { Host versus } \\
\text { consomic }\end{array}$ \\
\hline \multicolumn{6}{|l|}{$\begin{array}{l}\text { Risk assessment (significant strain difference: } \\
\quad P<0.002002)\end{array}$} \\
\hline Total number of risk assessments (frequency) & $2.0(2.0)$ & $5.0(6.0)$ & $4.0(5.0)$ & $* 0.000000^{\mathrm{M}}$ & $* 0.000278^{\mathrm{M}}$ \\
\hline Latency until the first risked assessment (s) & $93.2 \pm 24.2$ & $44.1 \pm 13.8$ & $55.4 \pm 19.1$ & $\begin{array}{c}0.296661^{\mathrm{M}} \text { and } \\
0.1241^{\mathrm{L}}\end{array}$ & $\begin{array}{c}0.115805^{\mathrm{WM}} \text { and } \\
0.0975^{\mathrm{L}}\end{array}$ \\
\hline \multicolumn{6}{|l|}{$\begin{array}{l}\text { Undirected explorations (significant strain } \\
\text { difference: } P<0.000668 \text { ) }\end{array}$} \\
\hline Total number of rearings in the box (frequency) & $42.0(15.0)$ & $12.5(11.0)$ & $38.0(13.0)$ & $* 0.000000^{\mathrm{M}}$ & $0.006278^{\mathrm{M}}$ \\
\hline Latency until the first rearing in the box (s) & $37.9 \pm 3.0$ & $42.9 \pm 10.9$ & $42.3 \pm 3.7$ & $\begin{array}{l}0.658465^{\mathrm{W}} \text { and } \\
0.9902^{\mathrm{L}}\end{array}$ & $\begin{array}{c}0.365358^{\mathrm{W}} \text { and } \\
0.2980^{\mathrm{L}}\end{array}$ \\
\hline Total number of rearings on the board (frequency) & $0.0(0.0)$ & $0.0(0.3)$ & $0.0(0.0)$ & $0.050114^{\mathrm{M}}$ & $1.000000^{\mathrm{M}}$ \\
\hline Latency until the first rearing on the board (s) & $299.9 \pm 0.1$ & $273.4 \pm 12.1$ & $300.0 \pm 0.0$ & $\begin{array}{c}0.025166^{\mathrm{W}} \text { and } \\
0.0311^{\mathrm{L}}\end{array}$ & $\begin{array}{c}1.000000^{\mathrm{W}} \text { and } \\
0.3173^{\mathrm{L}}\end{array}$ \\
\hline Total number of hole explorations (frequency) & $8.0(19.0)$ & $0.0(4.5)$ & $5.0(18.0)$ & $* 0.000000^{\mathrm{M}}$ & $0.001852^{\mathrm{M}}$ \\
\hline Latency until the first hole exploration (s) & $60.8 \pm 5.6$ & $228.0 \pm 18.0$ & $126.4 \pm 18.4$ & $\begin{array}{l}* \mathbf{0 . 0 0 0 0 0 0}^{\mathrm{M}} \text { and } \\
\quad * \mathbf{0 . 0 0 0 0}^{\mathrm{L}}\end{array}$ & $\begin{array}{c}0.001776^{\mathrm{W}} \text { and } \\
0.0008^{\mathrm{L}}\end{array}$ \\
\hline \multicolumn{6}{|l|}{$\begin{array}{l}\text { Directed explorations (significant strain difference: } \\
\quad P<0.000668 \text { ) }\end{array}$} \\
\hline Total number of rearings on holes visited & $0.0(0.0)$ & $0.0(0.0)$ & $0.0(0.0)$ & $0.460684^{\mathrm{M}}$ & $0.490566^{\mathrm{M}}$ \\
\hline Latency until the first hole visited (s) & $299.9 \pm 0.0$ & $289.4 \pm 6.6$ & $300.0 \pm 0.0$ & $\begin{array}{c}0.425341^{\mathrm{M}} \text { and } \\
0.4348^{\mathrm{L}}\end{array}$ & $\begin{array}{c}0.496566^{\mathrm{M}} \text { and } \\
0.1534^{\mathrm{L}}\end{array}$ \\
\hline Total number of unfamiliar object explorations (frequency) & $8.0(3.0)$ & $2.0(2.0)$ & $7.0(4.0)$ & $* 0.000000^{\mathrm{M}}$ & $0.581983^{\mathrm{M}}$ \\
\hline Latency until the first unfamiliar object exploration (s) & $42.3 \pm 2.9$ & $121.1 \pm 19.3$ & $69.9 \pm 9.8$ & $\begin{array}{l}* \mathbf{0 . 0 0 0 3 3 7} 7^{\mathrm{W}} \text { and } \\
\quad * \mathbf{0 . 0 0 0 1}^{\mathrm{L}}\end{array}$ & $\begin{array}{c}0.011443^{\mathrm{W}} \text { and } \\
0.0011^{\mathrm{L}}\end{array}$ \\
\hline $\begin{array}{l}\text { Percentage of time being busy with unfamiliar object } \\
\text { explorations }(\%)\end{array}$ & $2.5 \pm 0.5$ & $1.3 \pm 0.2$ & $2.0 \pm 0.3$ & $0.003837^{\mathrm{M}}$ & $0.387650^{\mathrm{W}}$ \\
\hline Average duration of an unfamiliar object exploration (s) & $1.0 \pm 0.2$ & $1.2 \pm 0.2$ & $0.9 \pm 0.2$ & $0.665362^{\mathrm{M}}$ & $0.346404^{\mathrm{M}}$ \\
\hline \multicolumn{6}{|l|}{ Memory (significant strain difference: $P<0.001002$ ) } \\
\hline Total number of familiar object explorations (frequency) & $8.0(4.0)$ & $3.0(2.3)$ & $10.0(5.0)$ & $* 0.000000^{\mathrm{M}}$ & $0.200291^{\mathrm{M}}$ \\
\hline Latency until the first familiar object exploration (s) & $47.7 \pm 4.3$ & $129.5 \pm 21.4$ & $59.4 \pm 7.1$ & $\begin{array}{c}* \mathbf{0 . 0 0 0 7 5 2} 2^{\mathrm{W}} \text { and } \\
0.0011^{\mathrm{L}}\end{array}$ & $\begin{array}{c}0.165098^{\mathrm{W}} \text { and } \\
0.1164^{\mathrm{L}}\end{array}$ \\
\hline $\begin{array}{l}\text { Percentage of time being busy with familiar object exploration } \\
(\%)\end{array}$ & $1.4 \pm 0.1$ & $1.0 \pm 0.1$ & $2.0 \pm 0.2$ & $0.035999^{\mathrm{S}}$ & $0.054209^{\mathrm{W}}$ \\
\hline Average duration of a familiar object exploration (s) & $0.5 \pm 0.0$ & $1.4 \pm 0.4$ & $0.6 \pm 0.1$ & $0.016086^{w}$ & $0.171121^{\mathrm{S}}$ \\
\hline \multicolumn{6}{|l|}{ Locomotion (significant strain difference: $P<0.002002$ ) } \\
\hline Total number of line crossings (frequency) & $151.0(25.0)$ & $26.0(36.0)$ & $153.0(18.0)$ & $* 0.000000^{\mathrm{M}}$ & $0.670813^{\mathrm{M}}$ \\
\hline Latency until the first line crossing (s) & $10.0 \pm 1.2$ & $32.8 \pm 11.5$ & $9.4 \pm 1.6$ & $\begin{array}{c}0.101683^{\mathrm{M}} \text { and } \\
0.0208^{\mathrm{L}}\end{array}$ & $\begin{array}{l}0.739813^{\mathrm{W}} \text { and } \\
0.8496^{\mathrm{L}}\end{array}$ \\
\hline \multicolumn{6}{|l|}{ Arousal (significant strain difference: $P<0.000668$ ) } \\
\hline Total number of groomings (frequency) & $1.0(0.0)$ & $1.0(1.3)$ & $1.0(1.0)$ & $0.002225^{\mathrm{M}}$ & $0.362890^{\mathrm{M}}$ \\
\hline Latency until the first grooming (s) & $211.8 \pm 14.9$ & $156.5 \pm 14.6$ & $235.4 \pm 13.1$ & $\begin{array}{c}0.010409^{\mathrm{S}} \text { and } \\
0.0135^{\mathrm{L}}\end{array}$ & $\begin{array}{c}0.238194^{\mathrm{S}} \text { and } \\
0.2234^{\mathrm{L}}\end{array}$ \\
\hline Percentage of time being busy with grooming (\%) & $1.0 \pm 0.1$ & $6.1 \pm 1.0$ & $0.8 \pm 0.2$ & $* 0.000010^{\mathrm{W}}$ & $0.643112^{\mathrm{s}}$ \\
\hline Average duration of a grooming (s) & $2.6 \pm 0.4$ & $12.6 \pm 2.9$ & $2.1 \pm 0.5$ & $* 0.000001^{\mathrm{M}}$ & $0.482561^{\mathrm{S}}$ \\
\hline Total number of boli (frequency) & $0.0(1.0)$ & $0.0(1.0)$ & $0.0(1.0)$ & $0.635285^{\mathrm{M}}$ & $0.779869^{\mathrm{M}}$ \\
\hline Latency until the first bolus is produced (s) & $198.0 \pm 26.3$ & $205.0 \pm 21.0$ & $227.0 \pm 22.9$ & $\begin{array}{c}0.852796^{\mathrm{M}} \text { and } \\
0.7893^{\mathrm{L}}\end{array}$ & $\begin{array}{c}0.386284^{\mathrm{M}} \text { and } \\
0.4648^{\mathrm{L}}\end{array}$ \\
\hline \multicolumn{6}{|l|}{ (Bivariate analysis) } \\
\hline \multicolumn{4}{|c|}{ Latency until the first grooming + percentage of time being busy with grooming } & $* 0.000002^{\mathrm{H}}$ & $0.494703^{\mathrm{H}}$ \\
\hline \multicolumn{4}{|l|}{ Latency until the first grooming + average duration of a grooming } & $* 0.000170^{\mathrm{H}}$ & $0.495809^{\mathrm{H}}$ \\
\hline \multicolumn{6}{|l|}{ Other behavior (significant strain difference: $P<0.000801$ ) } \\
\hline Number of times the mouse is in the box (frequency) & $28.0(9.0)$ & $14.5(8.3)$ & $23.0(13.0)$ & $* 0.000000^{\mathrm{M}}$ & $0.012238^{\mathrm{M}}$ \\
\hline
\end{tabular}


Table 5 continued

\begin{tabular}{|c|c|c|c|c|c|}
\hline \multirow[t]{2}{*}{ Behavioral dimension/parameter } & \multirow{2}{*}{$\begin{array}{l}\text { C57BL/6J } \\
\text { (host } \\
\text { strain) }\end{array}$} & \multirow{2}{*}{$\begin{array}{l}\mathrm{A} / \mathrm{J} \\
\text { (donor } \\
\text { strain) }\end{array}$} & \multirow{2}{*}{$\begin{array}{l}\text { CSS-19 } \\
\text { (consomic } \\
\text { line) }\end{array}$} & \multicolumn{2}{|l|}{$P$ value } \\
\hline & & & & $\begin{array}{l}\text { Host versus } \\
\text { donor }\end{array}$ & $\begin{array}{l}\text { Host versus } \\
\text { consomic }\end{array}$ \\
\hline Percentage of time in the box $(\%)$ & $88.5 \pm 1.0$ & $79.4 \pm 1.7$ & $92.4 \pm 0.9$ & $* 0.000029^{\mathrm{W}}$ & $* 0.000000^{\mathrm{S}}$ \\
\hline Average duration of a stay in the box (s) & $9.9 \pm 0.5$ & $19.1 \pm 1.6$ & $13.6 \pm 1.0$ & $* \mathbf{0 . 0 0 0 0 0 5}^{w}$ & $0.001972^{\mathrm{W}}$ \\
\hline Total number of urinations (frequency) & $0.0(0.0)$ & $0.0(0.0)$ & $0.0(1.0)$ & $0.008157^{\mathrm{M}}$ & $0.223778^{\mathrm{M}}$ \\
\hline Latency until the first time urine is produced (s) & $245.1 \pm 20.7$ & $300.0 \pm 0.0$ & $202.2 \pm 25.1$ & $\begin{array}{c}0.008157^{\mathrm{M}} \text { and } \\
0.2244^{\mathrm{L}}\end{array}$ & $\begin{array}{c}0.298815^{\mathrm{M}} \text { and } \\
0.2537^{\mathrm{L}}\end{array}$ \\
\hline
\end{tabular}

Values are means \pm SEM (latency, percentage and average duration) or medians with, in parentheses, the interquartile range (frequency) for 27 (C57BL/6J and CSS-19) or 30 (A/J) animals per strain. Note that a $P$ value of 0.000000 (Student's $t$ tests and Mann-Whitney $U$ tests) or 0.0000 (Log-Rank tests) does not mean that it is zero, only that it is less than 0.0000005 or 0.00005 , respectively. Significant (*) strain differences are indicated in bold characters

$\mathrm{H}=$ Hotelling's $T^{2}$ test, $\mathrm{M}=$ Mann-Whitney $U$ test, $\mathrm{S}=$ Student's $t$ test, $\mathrm{W}=$ Student's $t$ test with Welch-Satterthwaite correction, $\mathrm{L}=\mathrm{Log}$ Rank test
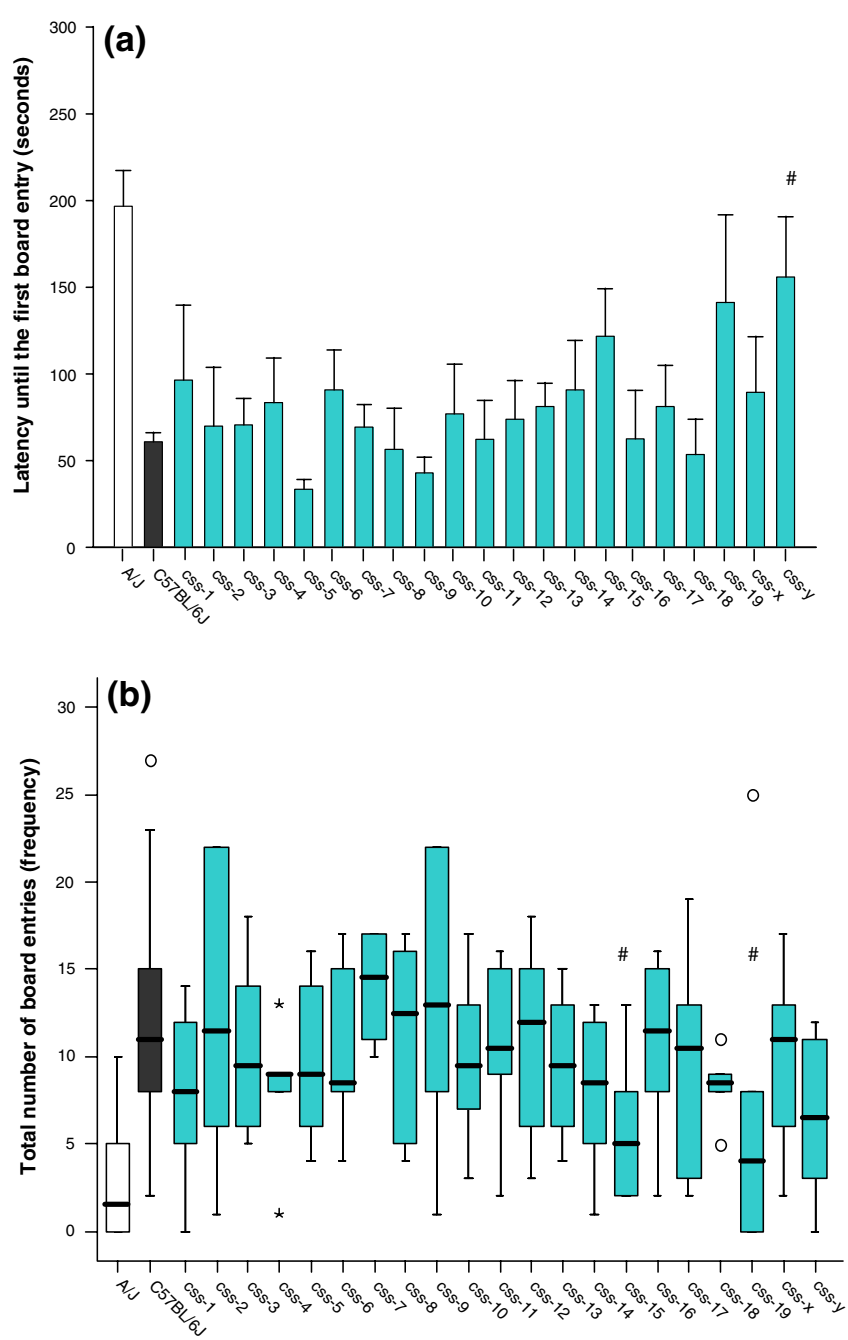

Fig. 3 Anxiety-related behavior in the modified hole board. Results for 20 CSSs ( $n=6 /$ consomic strain), the C57BL/6J host strain $(n=27)$, and $\mathrm{A} / \mathrm{J}$ donor strain $(n=30)$. (a) Latency until the first board entry; (b) Total number of board entries; (c) Percentage of time spent on the board; (d) Average duration of a board entry. Results are presented as

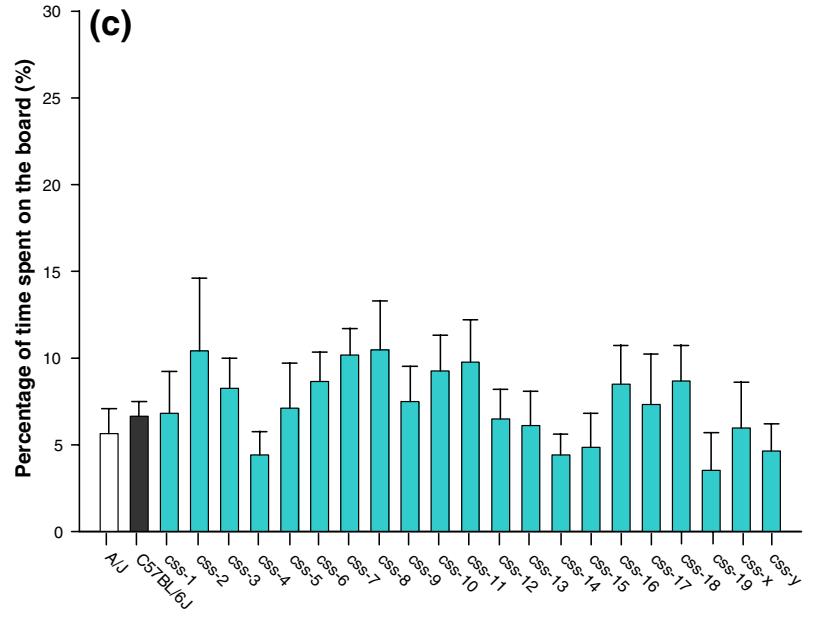

(d)

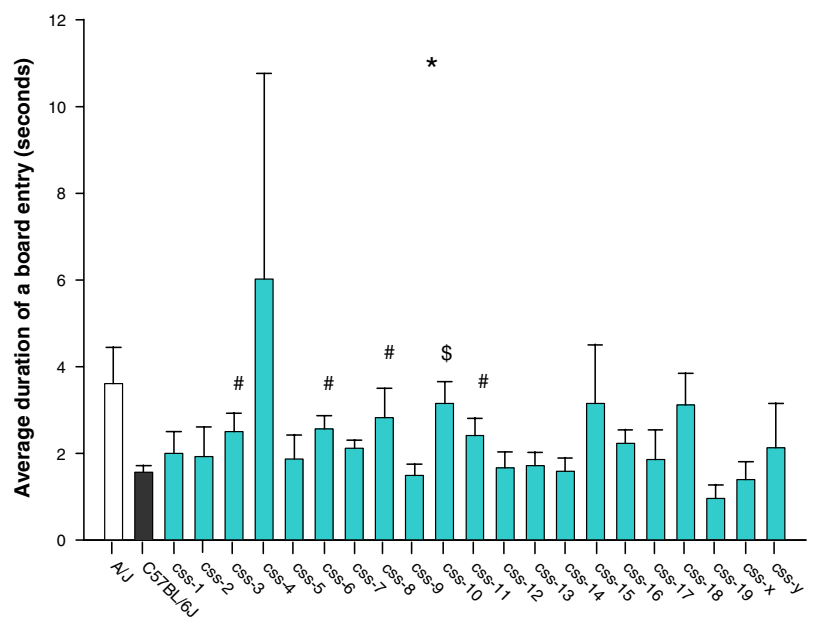

means + SEM (diagrams a, c, and d) or box plots (diagram b). Significant $(P<0.001002)$ and suggestive $(0.001002 \leq P<0.012741)$ evidence for an anxiety QTL on a particular chromosome is indicated by $\$$ and \#, respectively. In diagrams (b) and (d) outliers and extreme cases are indicated with o and *, respectively 
anxiety could be excluded. After behavioral testing the statistical analysis was repeated, but with 27 animals for both the chromosome substitution strain and the host strain (C57BL/6J). The suggestive evidence for an anxiety QTL (or QTLs) on chromosome 19 (detected with 27 host strain versus 6 CSS-19 animals; Table 6, bivariate analysis) now turns into a significant evidence (Table 4). The evidence for a risk assessment QTL on chromosome 19 remains significant, whereas there was no longer evidence for a direct exploration QTL (Table 5). In addition, significant evidence for a QTL for percentage of time in the box on this chromosome turned up (Table 5).

Factor analysis

This analysis included the total numbers, latencies and relative durations of all behavioral parameters. A specific assumption for a factor analysis is that a parameter should not be fully derived from one or more of the other included parameters. Therefore, average durations of the behavioral parameters were not included, because these parameters are based on the parameters percentage of time and total number. In contrast to the Hotelling's $T^{2}$ test for factor analysis multivariate normality is not required, thus it is allowed to include the total numbers of the behavioral parameters. Nine clear factors emerged accounting for $74.5 \%$ of the total variance (Table 8 ). Factor 2 explained $11.4 \%$ of the total variance and appeared to reflect mainly anxiety, since the parameters total number of board entries, latency until the first board entry, and percentage of time on the board loaded highly on this factor. However, it should be noted that total number of hole explorations, latency until the first hole exploration and number of times the mouse is in the box also loaded highly on this factor.

Table 9 summarizes suggestive and significant evidence for a QTL on a chromosome for the extracted, orthogonal factors. Factor analysis greatly reduced the total number of

Table 6 Suggestive and significant evidence for QTLs influencing the difference in anxiety-related behavior between C57BL/6J $(n=27)$ and consomic $(n=6)$ male mice

\begin{tabular}{|c|c|c|c|c|c|c|c|}
\hline \multirow{2}{*}{$\begin{array}{l}\text { Consomic } \\
\text { line }\end{array}$} & \multicolumn{5}{|c|}{ Univariate analysis ( $P$ value $)$} & \multicolumn{2}{|c|}{$\frac{\text { Bivariate analyses ( } P \text { value })}{\text { Latency until the first board entry plus }}$} \\
\hline & \multicolumn{2}{|c|}{$\begin{array}{l}\text { Latency until the first } \\
\text { board entry }\end{array}$} & $\begin{array}{l}\text { Total number of } \\
\text { board entries }\end{array}$ & $\begin{array}{l}\text { Percentage of time } \\
\text { spent on the board }\end{array}$ & $\begin{array}{l}\text { Average duration } \\
\text { of a board entry }\end{array}$ & $\begin{array}{l}\text { Percentage of time } \\
\text { spent on the board }\end{array}$ & $\begin{array}{l}\text { Average duration } \\
\text { of a board entry }\end{array}$ \\
\hline CSS-1 & $0.449123^{\mathrm{W}}$ & $0.2429^{\mathrm{L}}$ & $0.154187^{\mathrm{M}}$ & $0.934940^{\mathrm{S}}$ & $0.308524^{\mathrm{S}}$ & $0.258690^{\mathrm{H}}$ & $0.100812^{\mathrm{H}}$ \\
\hline CSS-2 & $0.795155^{\mathrm{W}}$ & $0.7160^{\mathrm{L}}$ & $0.972744^{\mathrm{M}}$ & $0.418021^{\mathrm{W}}$ & $0.624447^{\mathrm{W}}$ & $0.214112^{\mathrm{H}}$ & $0.608261^{\mathrm{H}}$ \\
\hline CSS-3 & $0.486352^{\mathrm{S}}$ & $0.4439^{\mathrm{L}}$ & $0.546447^{\mathrm{M}}$ & $0.424047^{\mathrm{S}}$ & $0.027449^{\mathrm{S}}$ & $0.589949^{\mathrm{H}}$ & $0.090978^{\mathrm{H}}$ \\
\hline CSS-4 & $0.677603^{\mathrm{W}}$ & $0.2520^{\mathrm{L}}$ & $0.168883^{\mathrm{M}}$ & $0.178726^{\mathrm{S}}$ & $0.437896^{\mathrm{W}}$ & $0.362718^{\mathrm{H}}$ & $0.098401^{\mathrm{H}}$ \\
\hline CSS-5 & $0.052928^{\mathrm{S}}$ & $\# 0.0029^{\mathrm{L}}$ & $0.416687^{\mathrm{M}}$ & $0.441484^{\mathrm{S}}$ & $0.050840^{\mathrm{S}}$ & $0.134911^{\mathrm{H}}$ & $0.016677^{\mathrm{H}}$ \\
\hline CSS-6 & $0.250479^{\mathrm{W}}$ & $0.0971^{\mathrm{L}}$ & $0.559561^{\mathrm{M}}$ & $0.326912^{\mathrm{S}}$ & $0.013329^{\mathrm{S}}$ & $0.077632^{\mathrm{H}}$ & $0.017935^{\mathrm{H}}$ \\
\hline CSS-7 & $0.522299^{\mathrm{S}}$ & $0.3902^{\mathrm{L}}$ & $0.217356^{\mathrm{M}}$ & $0.084428^{S}$ & $0.135360^{\mathrm{S}}$ & $0.150948^{\mathrm{H}}$ & $0.301522^{\mathrm{H}}$ \\
\hline CSS-8 & $0.788546^{\mathrm{S}}$ & $0.9922^{\mathrm{L}}$ & $0.954535^{\mathrm{M}}$ & $0.096054^{\mathrm{S}}$ & $\# 0.011709^{\mathrm{S}}$ & $0.254198^{\mathrm{H}}$ & $0.042008^{\mathrm{H}}$ \\
\hline CSS-9 & $0.167417^{\mathrm{S}}$ & $0.1041^{\mathrm{L}}$ & $0.690026^{\mathrm{M}}$ & $0.686224^{\mathrm{S}}$ & $0.862264^{\mathrm{S}}$ & $0.371587^{\mathrm{H}}$ & $0.383723^{\mathrm{H}}$ \\
\hline CSS-10 & $0.362698^{\mathrm{S}}$ & $0.4938^{\mathrm{L}}$ & $0.485679^{\mathrm{M}}$ & $0.211063^{\mathrm{S}}$ & $* 0.000704^{\mathrm{S}}$ & $0.228876^{\mathrm{H}}$ & $\# 0.003026^{\mathrm{H}}$ \\
\hline CSS-11 & $0.946635^{\mathrm{W}}$ & $0.4959^{\mathrm{L}}$ & $0.829091^{\mathrm{M}}$ & $0.155609^{\mathrm{S}}$ & $0.042604^{\mathrm{S}}$ & $0.312431^{\mathrm{H}}$ & $0.127455^{\mathrm{H}}$ \\
\hline CSS-12 & $0.599561^{\mathrm{W}}$ & $0.2407^{\mathrm{L}}$ & $0.882397^{\mathrm{M}}$ & $0.937677^{\mathrm{S}}$ & $0.777740^{\mathrm{S}}$ & $0.717798^{\mathrm{H}}$ & $0.713713^{\mathrm{H}}$ \\
\hline CSS-13 & $0.137512^{\mathrm{S}}$ & $0.2549^{\mathrm{L}}$ & $0.390433^{\mathrm{M}}$ & $0.795626^{\mathrm{S}}$ & $0.679103^{S}$ & $0.337925^{\mathrm{H}}$ & $0.327658^{\mathrm{H}}$ \\
\hline CSS-14 & $0.344671^{\mathrm{W}}$ & $0.0969^{\mathrm{L}}$ & $0.134129^{\mathrm{M}}$ & $0.251965^{\mathrm{S}}$ & $0.950503^{\mathrm{S}}$ & $0.189808^{\mathrm{H}}$ & $0.251590^{\mathrm{H}}$ \\
\hline CSS-15 & $0.076108^{\mathrm{W}}$ & $0.0171^{\mathrm{L}}$ & $0.013522^{\mathrm{M}}$ & $0.383342^{\mathrm{S}}$ & $0.293972^{\mathrm{W}}$ & $\# 0.005532^{\mathrm{H}}$ & $* 0.000423^{\mathrm{H}}$ \\
\hline CSS-16 & $0.943756^{\mathrm{W}}$ & $0.9258^{\mathrm{L}}$ & $0.810311^{\mathrm{M}}$ & $0.384557^{\mathrm{S}}$ & $0.085790^{\mathrm{S}}$ & $0.642054^{\mathrm{H}}$ & $0.233626^{\mathrm{H}}$ \\
\hline CSS-17 & $0.446468^{\mathrm{S}}$ & $0.1971^{\mathrm{L}}$ & $0.515115^{\mathrm{M}}$ & $0.835273^{\mathrm{W}}$ & $0.694079^{\mathrm{W}}$ & $0.380317^{\mathrm{H}}$ & $0.389096^{\mathrm{H}}$ \\
\hline CSS-18 & $0.636484^{\mathrm{S}}$ & $0.7798^{\mathrm{L}}$ & $0.133892^{\mathrm{M}}$ & $0.336169^{\mathrm{S}}$ & $0.087818^{\mathrm{W}}$ & $0.601366^{\mathrm{H}}$ & $\# 0.010215^{\mathrm{H}}$ \\
\hline CSS-19 & $0.173463^{\mathrm{W}}$ & $0.0803^{\mathrm{L}}$ & $0.038287^{\mathrm{M}}$ & $0.146554^{\mathrm{S}}$ & $0.134412^{\mathrm{S}}$ & $0.012783^{\mathrm{H}}$ & $\# 0.011458^{\mathrm{H}}$ \\
\hline CSS-X & $0.421212^{\mathrm{W}}$ & $0.3573^{\mathrm{L}}$ & $0.576378^{\mathrm{M}}$ & $0.763177^{\mathrm{S}}$ & $0.697363^{S}$ & $0.335827^{\mathrm{H}}$ & $0.316004^{\mathrm{H}}$ \\
\hline CSS-Y & $0.040699^{\mathrm{W}}$ & $\# 0.0012^{\mathrm{L}}$ & $0.065561^{\mathrm{M}}$ & $0.318997^{\mathrm{S}}$ & $0.611008^{\mathrm{W}}$ & $* 0.000201^{\mathrm{H}}$ & $* 0.000187^{\mathrm{H}}$ \\
\hline
\end{tabular}

Significant evidence $(* P<0.001002)$ for a QTL on a chromosome is indicated in bold characters, whereas suggestive evidence (\#, $0.001002 \leq P$ $<0.012741)$ is in italics. $\mathrm{H}=$ Hotelling's $T^{2}$ test, $\mathrm{M}=$ Mann-Whitney $U$ test, $\mathrm{S}=$ Student's $t$ test, W $=$ Student's $t$ test with WelchSatterthwaite correction, $\mathrm{L}=$ Log-Rank test 


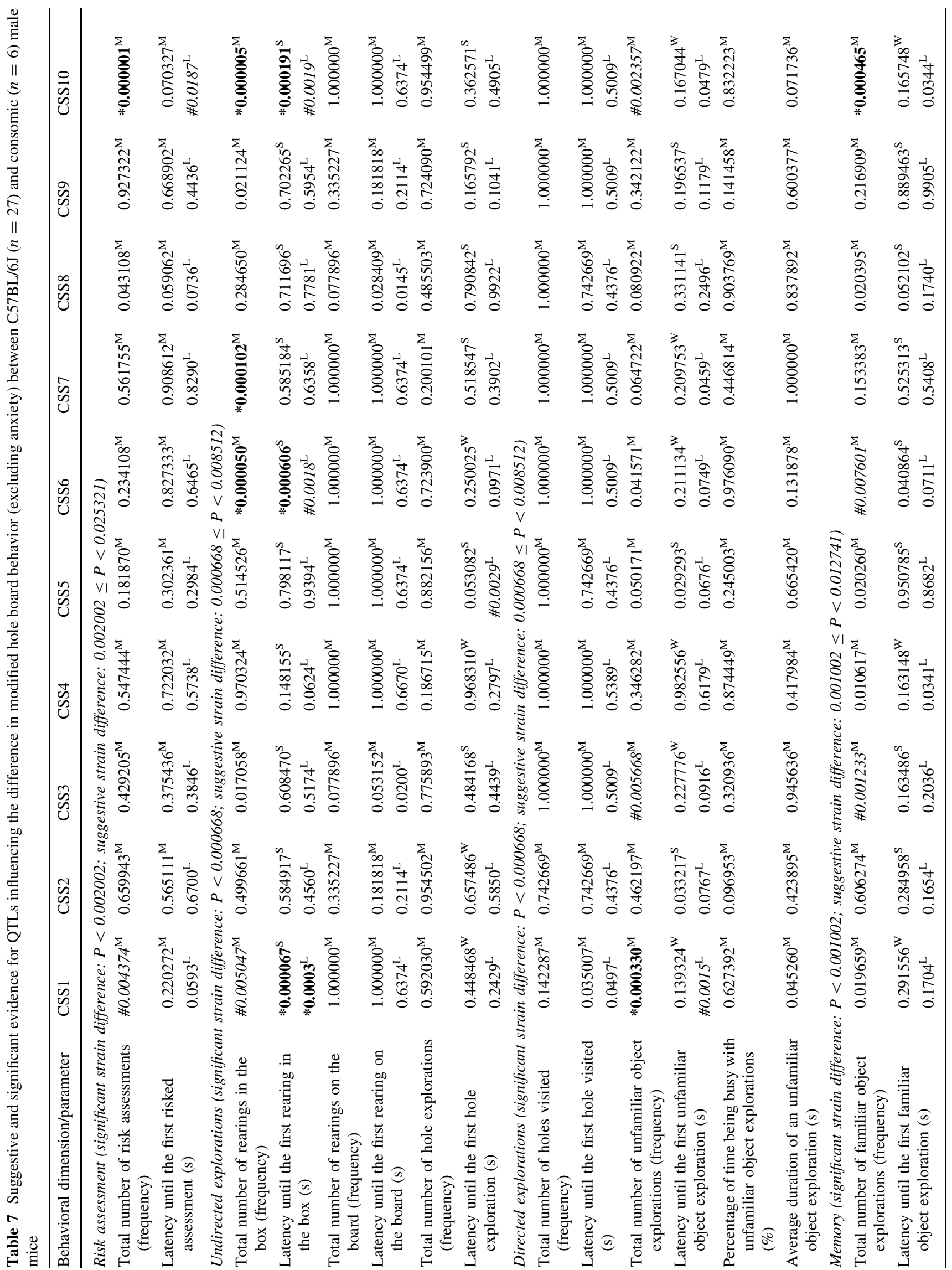




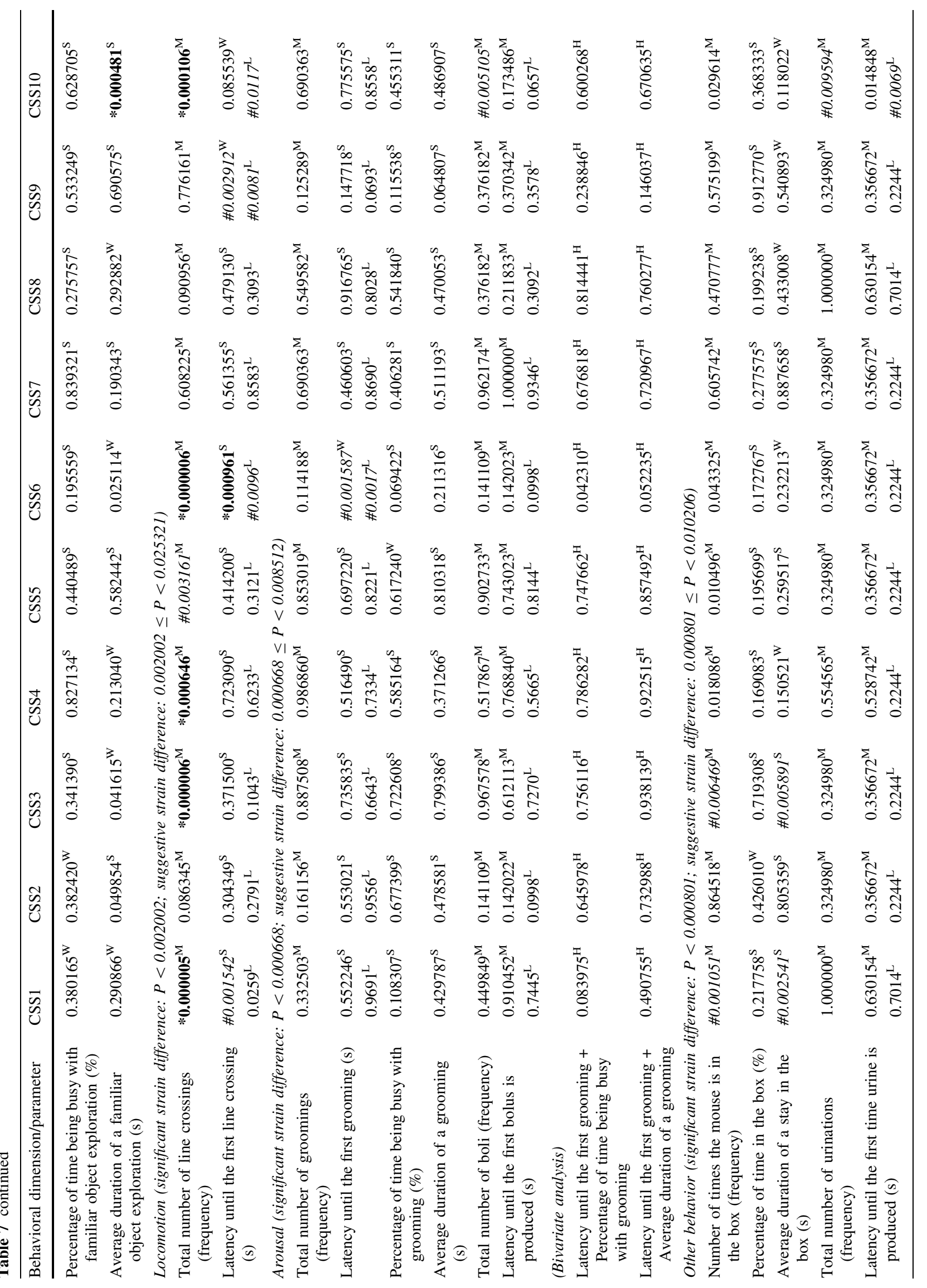




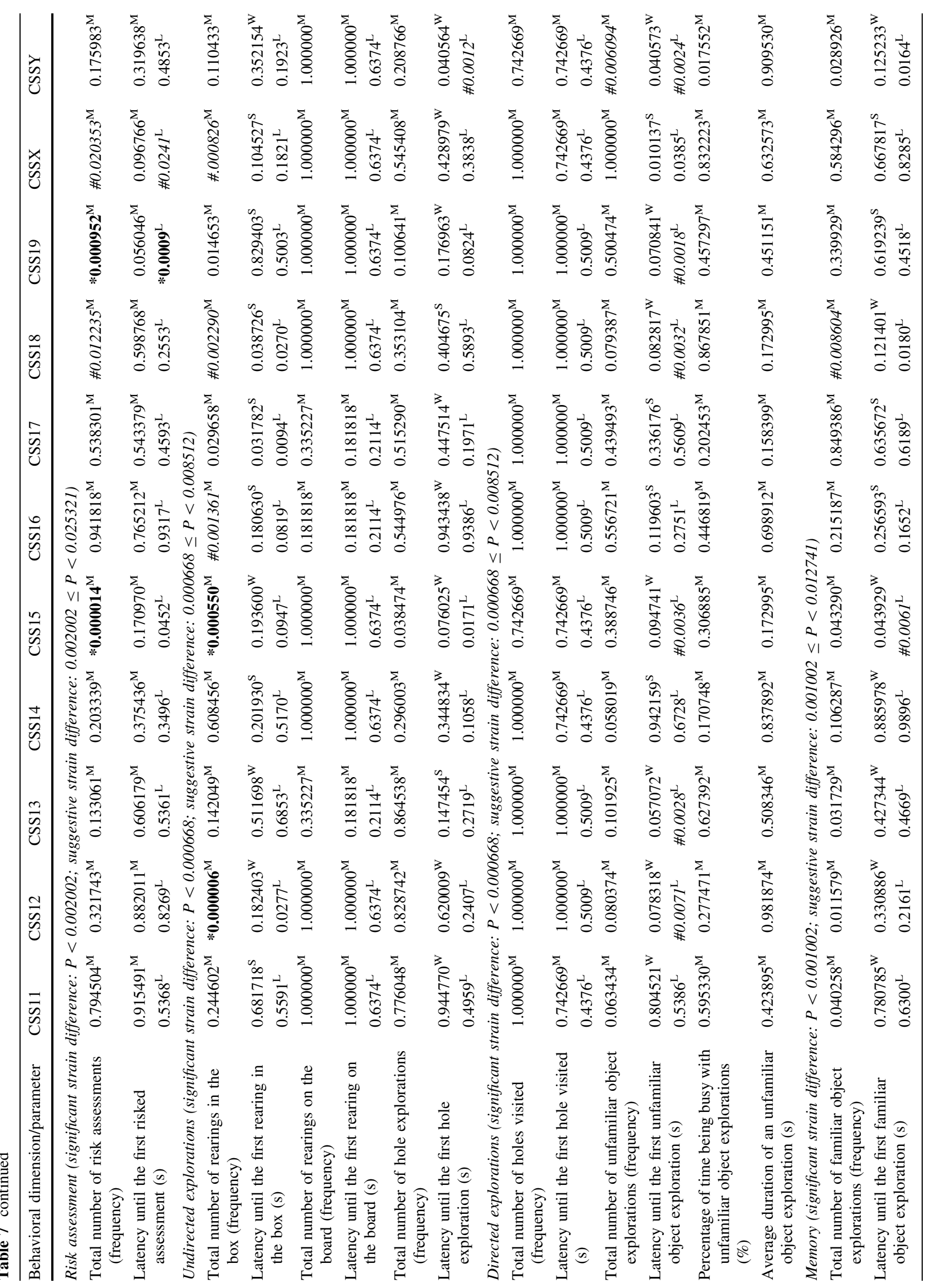




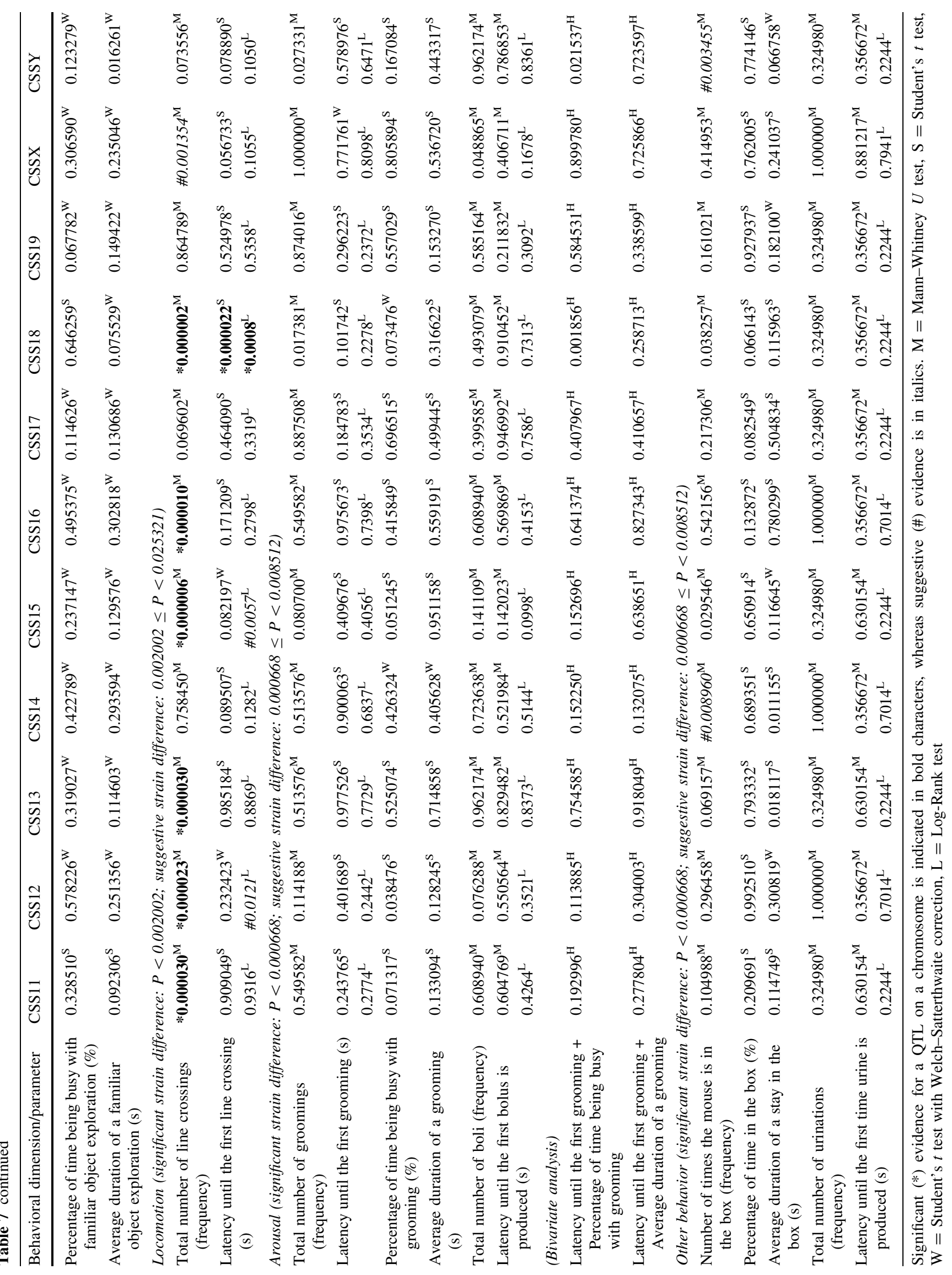


significant and suggestive QTLs as well as the number of chromosomes harboring a QTL, but in general these results are in line with those obtained with the individual parameters (compare Table 9 with Tables 4-7). Interestingly, for chromosome 17 there is now evidence that this chromosome also contains QTL(s) for modified hole board behavior. With respect to anxiety there was now only significant evidence for an anxiety QTL on chromosome 19. The narrow sense heritability of each factor was found to be within the expected range of behavioral phenotypes in mice (Valdar et al. 2006): 0.12-0.27 (Table 9).

\section{Discussion}

We examined a commercially available set of mouse chromosome substitution strains for which the parental strains differ in their anxiety-related behavior in the modified hole board test (Table 4, Figs. 2 and 3). In this study we implemented the Hotelling's $T^{2}$ test for identifying chromosomes that bear QTLs for anxiety-related behavior and compared the results obtained with this type of multivariate (bivariate) analysis with those from the univariate analyses (Student's $t$ test, Mann-Whitney $U$ test and LogRank test). Bivariate when compared with univariate analyses resulted in a slightly higher number of chromosomes with (significant) evidence for an anxiety QTL (Table 6), and the identified chromosomes were partly different: univariate analysis, chromosomes 5, 8, 10 and Y; bivariate analysis, chromosomes 10, 15, 18, 19 and $\mathrm{Y}$. Therefore, for the consomic survey we suggest to carry out both univariate and bivariate (genetic) analyses in parallel.

Table 10 gives an overview of the chromosomes for which there is evidence for a QTL influencing the difference in modified hole board behavior between C57BL/6J and $\mathrm{A} / \mathrm{J}$ mice. With respect to anxiety-related behavior, the present results for anxiety agreed well with previous genetic studies using the $\mathrm{A} / \mathrm{J}$ and $\mathrm{C} 57 \mathrm{BL} / 6 \mathrm{~J}$ as parental strains (Table 11). However, in contrast with the other (consomic) studies and probably as a result of the behavioral test we used (modified hole board), our results suggest that the transfer of the $\mathrm{Y}$ chromosome from the $\mathrm{A} / \mathrm{J}$ mouse onto the C57BL/6J background increased anxiety-related behavior (Fig. 3a and Table 6). Thus, genetic variation in genes on the $\mathrm{Y}$ chromosome may influence anxious behavior in the mouse. To the best of our knowledge this has not been described previously. Up until now association of the $\mathrm{Y}$ chromosome with behavioral traits in mice have only been reported for intermale aggression (e.g. Roubertoux et al. 1994). Intriguingly, Guillot and Chapouthier (1996) have found that males of more aggressive strains are also more anxious. Unfortunately, Guillot and Chapouthier (1996) did not test males from the
$\mathrm{A} / \mathrm{J}$ strain and it is well known that $\mathrm{A} / \mathrm{J}$ mice are markedly unaggressive (Brodkin et al. 2002). It can be concluded that if there is a relationship between intermale aggression and anxiety-related behavior it is certainly not a simple one. Sry (sex determining region of chromosome $\mathrm{Y}$ ), a transcription factor, might be a good candidate gene. The $3^{\prime}$-end of this mouse gene (i.e. the CAG trinucleotide repeat) shows strain and natural variants (Coward et al. 1994; Albrecht and Eicher 1997). Furthermore, based on the light-dark box and an $\mathrm{F}_{2}$ mapping population, there is evidence that the $\mathrm{X}$ chromosome also harbors a QTL influencing anxiety-related behavior (Table 11). Thus both $\mathrm{X}$ - and Y-linked QTLs might at least in part explain gender and strain differences in anxiety-related behavior.

It seems that almost all chromosomes, with the exception of chromosomes 2, 7, 12 and 16, carry QTL(s) that influence the difference in anxiety-related behavior between $\mathrm{C} 57 \mathrm{BL} / 6 \mathrm{~J}$ and $\mathrm{A} / \mathrm{J}$ mice (Table 11). Table 11 shows that significant evidence for anxiety QTLs is clustered mainly on chromosomes 1 (number of significant QTLs = 4), 10 (number of significant QTLs = 7) and 19 (number of significant QTLs $=4$ ). Willis-Owen and Flint (2006) inspected the literature and found largest quantity of evidence pointing towards the presence of one or more anxiety QTL on chromosome 1. In the present study, using the modified hole board test and avoidance behavior towards an unprotected area as anxiety parameter, we failed to detect an association with mouse chromosome 1 (Tables 6, 9 and 10, Fig. 3). Combining the results from Table 11 with those from Willis-Owen and Flint (2006) we may conclude that all mouse chromosomes (including both sex chromosomes) harbor genes that influence anxietyrelated behavior in the laboratory mouse.

The open field has been used as behavioral test for detecting QTLs influencing anxiety-related behavior in six mapping populations with $\mathrm{A} / \mathrm{J}$ and $\mathrm{C} 57 \mathrm{BL} / 6 \mathrm{~J}$ as progenitors: an $\mathrm{F}_{2}$ intercross, a set of recombinant inbred strains (RIS), a set of recombinant congenic strains (RCS), an advanced intercross population (AIL), a panel of interval-specific congenic strains (ISCS) and a panel of chromosome substitution strains (Table 11). The open field QTLs on chromosome 4 was only detected with RIS and those on chromosomes 17 and 18 were exclusively mapped with the RCS method (Table 11). This clearly illustrates why the use of more than one mapping population derived from the same parental strains is often advantageous (Bergeson et al. 2001). From Table 11 it can be seen that the open field QTL on chromosome 5 was up until now only detected with RIS. However, Singer et al. (2005) did not test a complete CSS panel: CSS-5 was at the time of testing not complete. Another reason for using more than one mapping population is the identification of gene-gene interactions. Chromosome substitution strains are not suitable for studies on epistatic 
Table 8 Orthogonal factor loadings for modified hole board behavioral parameters

Behavioral dimension/parameter DI/ME/LO AN/UN/OT AR OT

DI Factor 2

Eigenvalue

$\%$ Of the total variance

Anxiety (AN)

Total number of board entries

Latency until the first board entry

Percentage of time on the board

Risk assessment (RI)

Total number of risk assessments

Latency until the first risk assessment

Undirected exploration (UN)

Total number of rearings in the box

Latency until the first rearing in the box

Total number of rearings on the board

Latency until the first rearing on the board

Total number of hole explorations

Latency until the first hole exploration

Directed exploration (DI)

Total number of holes visited

Latency until the first hole visited

Total number of unfamiliar object explorations

Latency until the first unfamiliar object exploration

Percentage of time being busy with unfamiliar object explorations

Memory (ME)

Total number of familiar object explorations

Latency until the first familiar object exploration

Percentage of time being busy with familiar object exploration

Locomotion ( $L O)$

Total number of line crossings

Latency until the first line crossing

Arousal (AR)

Total number of groomings

Latency until the first grooming

Percentage of time being busy with grooming

Total number of boli

Latency until the first bolus is produced

Other behavior (OT)

Number of times the mouse is in the box

Percentage of time in the box

Total number of urinations

Latency until the first time urine is produced

Factor 3 Factor 4 Factor 5 Factor 6 Factor 7 Factor 8 Factor 9

$\begin{array}{lllllllll}7.58 & 3.42 & 2.53 & 1.82 & 1.79 & 1.59 & 1.31 & 1.21 & 1.11 \\ 25.3 & 11.4 & 8.4 & 6.1 & 6.0 & 5.3 & 4.4 & 4.0 & 3.7\end{array}$

\begin{tabular}{|c|c|c|c|c|c|c|c|c|}
\hline 0.237 & 0.910 & 0.088 & -0.004 & 0.015 & 0.039 & -0.088 & -0.017 & -0.036 \\
\hline-0.480 & -0.657 & 0.037 & -0.009 & 0.096 & -0.112 & 0.130 & 0.015 & 0.126 \\
\hline-0.019 & 0.864 & -0.065 & -0.084 & -0.264 & -0.094 & -0.007 & -0.055 & 0.080 \\
\hline-0.443 & -0.347 & 0.081 & 0.205 & -0.026 & 0.032 & 0.576 & 0.026 & -0.039 \\
\hline 0.121 & 0.137 & 0.079 & -0.206 & -0.002 & -0.060 & -0.656 & -0.113 & -0.065 \\
\hline 0.575 & 0.262 & 0.276 & 0.110 & -0.011 & 0.058 & -0.480 & 0.190 & -0.036 \\
\hline-0.029 & 0.012 & -0.036 & -0.141 & 0.049 & -0.125 & 0.726 & 0.069 & -0.009 \\
\hline 0.013 & 0.061 & -0.057 & -0.022 & 0.060 & 0.049 & -0.047 & -0.848 & 0.060 \\
\hline-0.046 & 0.031 & 0.037 & -0.017 & 0.071 & -0.005 & 0.099 & 0.821 & 0.033 \\
\hline 0.141 & 0.923 & 0.102 & -0.023 & -0.034 & -0.012 & -0.073 & -0.014 & -0.018 \\
\hline-0.521 & -0.664 & -0.069 & 0.000 & 0.047 & -0.067 & 0.137 & -0.061 & 0.143 \\
\hline 0.012 & 0.096 & -0.004 & 0.007 & -0.906 & 0.007 & -0.060 & -0.036 & -0.039 \\
\hline-0.023 & -0.088 & -0.053 & -0.003 & 0.897 & -0.018 & -0.017 & -0.023 & 0.034 \\
\hline 0.694 & 0.224 & 0.081 & 0.150 & 0.175 & 0.200 & 0.027 & 0.169 & 0.194 \\
\hline-0.751 & -0.228 & 0.124 & -0.008 & 0.075 & -0.051 & 0.171 & 0.142 & -0.128 \\
\hline 0.113 & 0.039 & 0.037 & 0.045 & 0.119 & 0.174 & -0.056 & 0.157 & 0.679 \\
\hline 0.670 & 0.093 & 0.291 & 0.138 & 0.128 & -0.015 & -0.001 & 0.226 & 0.339 \\
\hline-0.721 & -0.274 & 0.026 & -0.018 & 0.161 & 0.070 & 0.167 & 0.106 & -0.173 \\
\hline 0.260 & -0.200 & 0.168 & -0.197 & -0.033 & -0.166 & 0.212 & -0.075 & 0.617 \\
\hline
\end{tabular}

$\begin{array}{rrrrrrrrr}\mathbf{0 . 7 0 2} & 0.231 & 0.366 & 0.089 & 0.147 & 0.092 & -0.195 & 0.227 & 0.006 \\ \mathbf{- 0 . 6 6 7} & -0.065 & 0.115 & 0.050 & 0.078 & -0.042 & -0.020 & 0.094 & 0.103 \\ & & & & & & & & \\ 0.078 & 0.026 & \mathbf{- 0 . 8 1 1} & -0.078 & 0.067 & -0.022 & 0.120 & -0.048 & -0.076 \\ -0.008 & 0.029 & \mathbf{0 . 8 2 4} & 0.111 & -0.065 & 0.020 & -0.026 & -0.014 & 0.099 \\ -0.361 & -0.196 & -0.584 & 0.027 & -0.168 & 0.154 & -0.080 & -0.126 & 0.161 \\ -0.076 & -0.016 & -0.015 & 0.191 & 0.025 & \mathbf{- 0 . 8 9 5} & 0.104 & 0.018 & -0.009 \\ 0.104 & 0.031 & -0.033 & -0.209 & -0.001 & \mathbf{0 . 8 7 9} & 0.026 & -0.044 & 0.061\end{array}$

\begin{tabular}{rrrrrrrrr}
0.459 & $\mathbf{0 . 7 4 9}$ & 0.040 & 0.073 & 0.134 & 0.088 & -0.099 & 0.078 & 0.149 \\
0.463 & -0.434 & 0.349 & 0.121 & 0.273 & 0.050 & 0.053 & 0.094 & -0.508 \\
0.096 & -0.019 & 0.103 & $\mathbf{0 . 9 1 3}$ & 0.004 & -0.231 & 0.038 & -0.006 & -0.007 \\
-0.069 & 0.037 & -0.111 & $\mathbf{- 0 . 9 2 1}$ & 0.010 & 0.192 & -0.038 & -0.012 & 0.064 \\
\hline
\end{tabular}

The data from all mice of this study $(n=204)$ were subject to factor analysis. The Kaiser-Meyer-Olkin measure is 0.742 , indicating a high sampling adequacy for the factor analysis. Bartlett's test of sphericity indicates that the factor model is appropriate $(P<0.0005)$. Factor loadings $>0.6$ are considered to be high and are indicated in bold. The nine factors account for $74.5 \%$ of the total variance. AN $=$ anxiety, RI $=$ risk assessment, $\mathrm{UN}=$ undirected exploration, $\mathrm{DI}=$ directed exploration, $\mathrm{ME}=$ memory, $\mathrm{LO}=$ locomotion, $\mathrm{AR}=$ arousal, $\mathrm{OT}=$ other behavior 
Table 9 Suggestive and significant evidence for QTLs influencing the difference in orthogonal factors between C57BL/6J ( $n=27)$, A/J $(n=30)$ and consomic $(n=6$ or $n=27)$ male mice and heritability $\left(h^{2}\right)$ of each orthogonal factor

\begin{tabular}{|c|c|c|c|c|c|c|c|c|c|}
\hline $\begin{array}{l}h^{2} \\
\text { Consomic line }\end{array}$ & $\begin{array}{l}\text { DI/ME/LO } \\
0.23 \\
\text { Factor } 1\end{array}$ & $\begin{array}{l}\text { AN/UN/OT } \\
0.19 \\
\text { Factor } 2\end{array}$ & $\begin{array}{l}\text { AR } \\
0.16 \\
\text { Factor } 3\end{array}$ & $\begin{array}{l}\text { OT } \\
0.28 \\
\text { Factor } 4\end{array}$ & $\begin{array}{l}\text { DI } \\
0.16 \\
\text { Factor } 5\end{array}$ & $\begin{array}{l}\text { AR } \\
0.15 \\
\text { Factor } 6\end{array}$ & $\begin{array}{l}\text { RI/UN } \\
0.27 \\
\text { Factor } 7\end{array}$ & $\begin{array}{l}\text { UN } \\
0.19 \\
\text { Factor } 8\end{array}$ & $\begin{array}{l}\text { DI/ME } \\
0.12 \\
\text { Factor } 9\end{array}$ \\
\hline CSS-1 & $* 0.002869^{\mathrm{S}}$ & $0.385539^{\mathrm{S}}$ & $0.638828^{\mathrm{S}}$ & $0.188532^{\mathrm{M}}$ & $0.120364^{\mathrm{W}}$ & $0.372230^{\mathrm{M}}$ & $* 0.000775^{S}$ & $0.193268^{\mathrm{S}}$ & $0.880718^{\mathrm{S}}$ \\
\hline CSS-2 & $0.467514^{\mathrm{W}}$ & $0.758224^{\mathrm{W}}$ & $0.764877^{\mathrm{s}}$ & $0.260266^{\mathrm{M}}$ & $0.348328^{\mathrm{W}}$ & $0.945636^{\mathrm{M}}$ & $0.585118^{\mathrm{S}}$ & $0.326374^{\mathrm{W}}$ & $0.814133^{\mathrm{S}}$ \\
\hline CSS-3 & $\# 0.006080^{\mathrm{S}}$ & $0.959452^{\mathrm{S}}$ & $0.849246^{\mathrm{S}}$ & $\# 0.035301^{\mathrm{M}}$ & $0.342586^{\mathrm{S}}$ & $0.423895^{\mathrm{M}}$ & $0.270202^{\mathrm{S}}$ & $0.142016^{\mathrm{W}}$ & $0.235089^{\mathrm{S}}$ \\
\hline CSS-4 & $0.140365^{\mathrm{S}}$ & $0.106764^{\mathrm{S}}$ & $0.704278^{\mathrm{S}}$ & $0.240913^{\mathrm{M}}$ & $0.665321^{\mathrm{S}}$ & $0.762782^{\mathrm{M}}$ & $0.384352^{\mathrm{S}}$ & $0.625712^{\mathrm{S}}$ & $0.166404^{\mathrm{S}}$ \\
\hline CSS-5 & $0.410666^{\mathrm{s}}$ & $0.865571^{\mathrm{S}}$ & $0.597058^{\mathrm{W}}$ & $\# 0.045260^{\mathrm{M}}$ & $0.342086^{\mathrm{W}}$ & $0.280658^{\mathrm{M}}$ & $0.604197^{\mathrm{S}}$ & $0.629578^{\mathrm{S}}$ & $0.223293^{\mathrm{S}}$ \\
\hline CSS-6 & $* 0.000892^{\mathrm{S}}$ & $0.800449^{\mathrm{S}}$ & $* 0.0018900^{\mathrm{W}}$ & $0.079910^{\mathrm{M}}$ & $0.789961^{\mathrm{S}}$ & $1.000000^{\mathrm{M}}$ & $\# 0.022981^{\mathrm{S}}$ & $0.219425^{\mathrm{S}}$ & $0.945246^{\mathrm{S}}$ \\
\hline CSS-7 & $\# 0.008106^{\mathrm{S}}$ & $0.218616^{\mathrm{S}}$ & $0.498230^{\mathrm{S}}$ & $0.119897^{\mathrm{M}}$ & $0.958739^{\mathrm{S}}$ & $0.568924^{\mathrm{M}}$ & $0.248440^{\mathrm{S}}$ & $0.117562^{\mathrm{S}}$ & $0.558485^{\mathrm{S}}$ \\
\hline CSS-8 & $0.055153^{\mathrm{S}}$ & $0.597808^{\mathrm{S}}$ & $0.485749^{\mathrm{S}}$ & $0.479295^{\mathrm{M}}$ & $0.319623^{\mathrm{S}}$ & $0.945636^{\mathrm{M}}$ & $0.317295^{\mathrm{S}}$ & $0.166314^{\mathrm{W}}$ & $0.557963^{\mathrm{S}}$ \\
\hline CSS-9 & $0.186902^{\mathrm{S}}$ & $0.609744^{\mathrm{S}}$ & $0.079279^{\mathrm{S}}$ & $0.051004^{\mathrm{M}}$ & $0.794201^{\mathrm{S}}$ & $0.909530^{\mathrm{M}}$ & $0.736204^{\mathrm{S}}$ & $\# 0.013222^{\mathrm{S}}$ & $0.435485^{\mathrm{S}}$ \\
\hline CSS-10 & $* 0.000028^{\mathrm{S}}$ & $0.477049^{\mathrm{S}}$ & $0.656405^{\mathrm{s}}$ & $0.088791^{\mathrm{M}}$ & $0.231005^{\mathrm{S}}$ & $0.057315^{\mathrm{M}}$ & $* 0.000139^{S}$ & $\# 0.009035^{\mathrm{s}}$ & $0.478910^{\mathrm{S}}$ \\
\hline CSS-11 & $\# 0.026001^{\mathrm{S}}$ & $0.803801^{\mathrm{S}}$ & $0.195953^{\mathrm{S}}$ & $0.108754^{\mathrm{M}}$ & $0.281451^{\mathrm{W}}$ & $0.665420^{\mathrm{M}}$ & $0.835975^{\mathrm{W}}$ & $0.500369^{\mathrm{S}}$ & $0.484871^{\mathrm{S}}$ \\
\hline CSS-12 & $\# 0.004699^{\mathrm{S}}$ & $0.817362^{\mathrm{S}}$ & $0.354524^{\mathrm{S}}$ & $0.108754^{\mathrm{M}}$ & $0.568399^{\mathrm{S}}$ & $0.071736^{\mathrm{M}}$ & $\# 0.012775^{\mathrm{S}}$ & $0.318477^{\mathrm{S}}$ & $0.374022^{\mathrm{S}}$ \\
\hline CSS-13 & $\# 0.018059^{\mathrm{S}}$ & $0.603338^{\mathrm{S}}$ & $0.339801^{\mathrm{S}}$ & $0.098387^{\mathrm{M}}$ & $0.643895^{\mathrm{S}}$ & $0.837892^{\mathrm{M}}$ & $0.077346^{\mathrm{S}}$ & $0.182564^{\mathrm{W}}$ & $0.400532^{\mathrm{S}}$ \\
\hline CSS-14 & $0.431757^{\mathrm{S}}$ & $0.065601^{\mathrm{S}}$ & $0.999431^{\mathrm{s}}$ & $0.423895^{\mathrm{M}}$ & $0.160641^{\mathrm{W}}$ & $0.347861^{\mathrm{M}}$ & $0.632126^{\mathrm{S}}$ & $0.583669^{\mathrm{S}}$ & $0.712059^{\mathrm{S}}$ \\
\hline CSS-15 & $0.051778^{\mathrm{S}}$ & $0.054616^{\mathrm{S}}$ & $0.266905^{\mathrm{s}}$ & $0.222446^{\mathrm{M}}$ & $0.338418^{\mathrm{W}}$ & $0.451151^{\mathrm{M}}$ & $* 0.000279^{S}$ & $0.722159^{\mathrm{S}}$ & $0.613346^{\mathrm{S}}$ \\
\hline CSS-16 & $0.054761^{\mathrm{S}}$ & $0.612627^{\mathrm{s}}$ & $0.562601^{\mathrm{s}}$ & $0.372230^{\mathrm{M}}$ & $0.565102^{\mathrm{S}}$ & $0.538219^{\mathrm{M}}$ & $0.258155^{\mathrm{S}}$ & $0.272934^{\mathrm{W}}$ & $0.342402^{\mathrm{S}}$ \\
\hline CSS-17 & $0.859001^{\mathrm{S}}$ & $0.598247^{\mathrm{S}}$ & $0.360360^{\mathrm{S}}$ & $\# 0.035301^{\mathrm{M}}$ & $0.567539^{\mathrm{S}}$ & $0.204997^{\mathrm{M}}$ & $0.082386^{\mathrm{S}}$ & $\# 0.006181^{\mathrm{S}}$ & $\# 0.020760^{\mathrm{S}}$ \\
\hline CSS-18 & $* \mathbf{0 . 0 0 1 9 6 8} 8^{\mathrm{S}}$ & $0.862802^{\mathrm{S}}$ & $0.141458^{\mathrm{W}}$ & $0.347861^{\mathrm{M}}$ & $0.825900^{\mathrm{S}}$ & $0.423895^{\mathrm{M}}$ & $\# 0.030589^{\mathrm{S}}$ & $0.545806^{\mathrm{S}}$ & $0.614157^{\mathrm{S}}$ \\
\hline CSS-19 $(n=6)$ & $0.578773^{\mathrm{S}}$ & $0.077985^{\mathrm{S}}$ & $0.177143^{\mathrm{S}}$ & $0.665420^{\mathrm{M}}$ & $0.667780^{\mathrm{S}}$ & $0.397594^{\mathrm{M}}$ & $\# 0.009561^{\mathrm{S}}$ & $0.264264^{\mathrm{S}}$ & $\# 0.043440^{\mathrm{S}}$ \\
\hline CSS-X & $0.641326^{\mathrm{S}}$ & $0.489276^{\mathrm{S}}$ & $0.581028^{\mathrm{S}}$ & $0.538219^{\mathrm{M}}$ & $0.292938^{\mathrm{W}}$ & $0.222446^{\mathrm{M}}$ & $* 0.000042^{\mathrm{W}}$ & $0.147080^{\mathrm{S}}$ & $0.552526^{\mathrm{S}}$ \\
\hline CSS-Y & $0.140447^{\mathrm{W}}$ & $\# 0.016268^{\mathrm{S}}$ & $0.579818^{\mathrm{S}}$ & $* 0.0014399^{\mathrm{M}}$ & $0.318307^{\mathrm{W}}$ & $0.108754^{\mathrm{M}}$ & $0.670873^{\mathrm{S}}$ & $0.624064^{\mathrm{S}}$ & $0.324276^{\mathrm{S}}$ \\
\hline $\mathrm{A} / \mathrm{J}$ & $* \mathbf{0 . 0 0 0 0 0 0}{ }^{\mathrm{W}}$ & $* 0.000005^{\mathrm{S}}$ & $*_{0.000034^{S}}$ & $0.674238^{\mathrm{M}}$ & $* 0.001930 \mathrm{M}$ & $0.697581^{\mathrm{M}}$ & $0.341429^{\mathrm{S}}$ & $* \mathbf{0 . 0 0 2 4 2 9} 9^{\mathrm{M}}$ & $0.746125^{\mathrm{S}}$ \\
\hline $\operatorname{CSS} 19(n=27)$ & $0.900181^{\mathrm{S}}$ & $* 0.000821^{\mathrm{S}}$ & $0.109817^{\mathrm{S}}$ & $0.371306^{\mathrm{M}}$ & $0.600606^{\mathrm{W}}$ & $0.449646^{\mathrm{M}}$ & $\# 0.011880^{\mathrm{S}}$ & $0.170484^{\mathrm{S}}$ & $0.798753^{\mathrm{S}}$ \\
\hline
\end{tabular}

Significant evidence $(* P<0.004)$ for a QTL on a chromosome is indicated in bold characters, whereas suggestive evidence $(\#, 0.004 \leq P$ $<0.05)$ is in italics

$\mathrm{M}=$ Mann-Whitney $U$ test, $\mathrm{S}=$ Student's $t$ test, $\mathrm{W}=$ Student's $t$ test with Welch-Satterthwaite correction

$\mathrm{AN}=$ anxiety, $\mathrm{RI}=$ risk assessment, $\mathrm{UN}=$ undirected exploration, $\mathrm{DI}=$ directed exploration, $\mathrm{ME}=$ memory, $\mathrm{LO}=$ locomotion, $\mathrm{AR}=$ arousal, $\mathrm{OT}=$ other behavior

interactions between QTLs on different chromosomes (i.e. identifying the chromosomes that contain the QTLs that interact with each other), but are a sensitive method in the search for additive QTLs or interacting QTLs on the same chromosome with relative small effects. Other mapping populations (i.e. $\mathrm{F}_{2}$ intercross, RIS, RCS and AIL) are more ideal for detecting interchromosomal, interlocus interactions. For instance Zhang et al. (2005), using the computer programme Map Manager QTX and AIL as mapping population, found (suggestive) evidence for epistatic interactions with respect to anxiety-related behavior between chromosomes $10 \& 1$ and chromosomes $19 \& 1$. To study this interaction it would be worthwhile to generate socalled double consomic lines.

Interestingly, based on three behavioral tests (light-dark box, open field and modified hole board) and five mapping populations $\left(\mathrm{F}_{2}\right.$, RIS, RCS, AIL and CSS) there is strong evidence for QTL(s) influencing the difference in anxiety- related behavior between $\mathrm{C} 57 \mathrm{BL} / 6 \mathrm{~J}$ and $\mathrm{A} / \mathrm{J}$ mice on chromosome 19 (Table 11). This prompted us-together with the finding that CSS-19 did not differ in locomotion from the C57BL/6J host strain (Table 10) - to focus on mouse chromosome 19. Other groups, e.g. the Wellcome Trust Centre for Human Genetics in Oxford, UK (Fullerton 2006; Willis-Owen and Flint 2006), have already focused on mouse chromosome 1 . Rat chromosome 1 is homologous mainly to mouse chromosome 7 . However, some rat chromosome 1 segments are syntenic to other mouse chromosomes (Pravenec et al. 1999). For example, there is strong conservation in genetic content between the entire mouse chromosome 19 and the distal part of the long arm of rat chromosome 1 (Yamasaki et al. 2001). FernándezTeruel et al. (2002) have found a suggestive QTL influencing anxiety on rat chromosome 1 . In addition, the whole genome search of Terenina-Rigaldie et al. (2003) also revealed a significant anxiety QTL on this rat chromosome. 
Table 10 Overview of suggestive and significant evidence for QTLs influencing the difference in modified hole board behavior between $\mathrm{C} 57 \mathrm{BL} / 6 \mathrm{~J}$ and $\mathrm{A} / \mathrm{J}$ mice

\begin{tabular}{|c|c|c|c|c|c|c|c|c|c|c|c|c|c|c|c|c|c|c|c|c|c|}
\hline \multirow[t]{2}{*}{ Behavioral dimension } & \multicolumn{21}{|c|}{ Chromosomes } \\
\hline & 1 & 2 & 3 & 4 & 5 & 6 & 7 & 8 & 9 & 10 & 11 & 12 & 13 & 14 & 15 & 16 & 17 & 18 & $19^{\mathrm{a}}$ & $\mathrm{X}$ & $Y$ \\
\hline Anxiety & - & - & - & - & $\mathrm{x}$ & - & - & $\mathrm{x}$ & - & $\mathbf{X}$ & - & - & - & - & $\mathbf{X}$ & - & - & $\mathrm{x}$ & $\mathbf{X}$ & - & \\
\hline Risk assessment & $\mathrm{x}$ & - & - & - & - & - & - & - & - & $\mathrm{x}$ & - & - & - & - & $\mathbf{X}$ & - & - & $\mathrm{x}$ & $\mathbf{X}$ & $\mathrm{x}$ & - \\
\hline Undirected exploration & $\mathbf{X}$ & - & - & - & $\mathrm{x}$ & $\mathbf{X}$ & $\mathbf{X}$ & - & - & $\mathbf{X}$ & - & $\mathbf{X}$ & - & - & $\mathbf{X}$ & $\mathrm{x}$ & - & $\mathrm{x}$ & - & $\mathrm{x}$ & $\mathrm{x}$ \\
\hline Directed exploration & $\mathbf{X}$ & - & - & - & - & - & - & - & - & $\mathrm{x}$ & - & $\mathrm{x}$ & $\mathrm{x}$ & - & $\mathrm{x}$ & - & - & $\mathrm{x}$ & - & - & $\mathrm{x}$ \\
\hline Memory & - & - & $\mathrm{x}$ & - & - & $\mathrm{x}$ & - & - & - & $\mathbf{X}$ & - & - & - & - & $\mathrm{x}$ & - & - & $\mathrm{x}$ & - & - & - \\
\hline Locomotion & $\mathbf{X}$ & - & $\mathbf{X}$ & $\mathbf{X}$ & $\mathrm{x}$ & $\mathbf{X}$ & - & - & $\mathrm{x}$ & $\mathbf{X}$ & $\mathbf{X}$ & $\mathbf{X}$ & $\mathbf{X}$ & - & $\mathbf{X}$ & $\mathbf{X}$ & - & $\mathbf{X}$ & - & $\mathrm{x}$ & - \\
\hline Arousal & - & - & - & - & - & $\mathrm{x}$ & - & - & - & $\mathrm{x}$ & - & - & - & - & - & - & - & - & - & - & - \\
\hline Other behavior & $\mathrm{x}$ & - & $\mathrm{x}$ & - & - & - & - & - & - & $\mathrm{x}$ & - & - & - & $\mathrm{x}$ & - & - & - & - & $\mathbf{X}$ & - & $\mathrm{x}$ \\
\hline Factor 1: DI/ME/LO & $\mathbf{X}$ & - & $\mathrm{x}$ & - & - & $\mathbf{X}$ & $\mathrm{x}$ & - & - & $\mathbf{X}$ & $\mathrm{x}$ & $\mathrm{x}$ & $\mathrm{x}$ & - & - & - & - & $\mathbf{X}$ & - & - & - \\
\hline Factor 2: AN/UN/OT & - & - & - & - & - & - & - & - & - & - & - & - & - & - & - & - & - & - & $\mathbf{X}$ & - & $\mathrm{x}$ \\
\hline Factor 3: AR & - & - & - & - & - & $X$ & - & - & - & - & - & - & - & - & - & - & - & - & - & - & - \\
\hline Factor 4: OT & - & - & $\mathrm{x}$ & - & $\mathrm{x}$ & - & - & - & - & - & - & - & - & - & - & - & $\mathrm{x}$ & - & - & - & $X$ \\
\hline Factor 5: DI & - & - & - & - & - & - & - & - & - & - & - & - & - & - & - & - & - & - & - & - & - \\
\hline Factor 6: AR & - & - & - & - & - & - & - & - & - & - & - & - & - & - & - & - & - & - & - & - & - \\
\hline Factor 7: RI/UN & $\mathbf{X}$ & - & - & - & - & $\mathrm{x}$ & - & - & - & $\mathbf{X}$ & - & $\mathrm{x}$ & - & - & $\mathbf{X}$ & - & - & $\mathrm{x}$ & - & $\mathbf{X}$ & - \\
\hline Factor 8: UN & - & - & - & - & - & - & - & - & $\mathrm{x}$ & $\mathrm{x}$ & - & - & - & - & - & - & $\mathrm{x}$ & - & - & - & - \\
\hline Factor 9: DI/ME & - & - & - & - & - & - & - & - & - & - & - & - & - & - & - & - & $\mathrm{x}$ & - & - & - & - \\
\hline
\end{tabular}

$\mathbf{X}=$ significant, $\mathrm{x}=$ suggestive, and $-=$ no evidence for a QTL on a particular chromosome. AN $=$ anxiety, RI $=$ risk assessment, $\mathrm{UN}=$ undirected exploration, $\mathrm{DI}=$ directed exploration, $\mathrm{ME}=$ memory, $\mathrm{LO}=$ locomotion, $\mathrm{AR}=$ arousal, $\mathrm{OT}=$ other behavior. ${ }^{\mathrm{a}} \mathrm{Based}$ on 27 host and 27 consomic mice (see Tables 4, 5 and 9)

Table 11 Suggestive and significant evidence for QTLs influencing the difference in anxiety-related behavior between C57BL/6J and A/J mice

\begin{tabular}{|c|c|c|c|c|c|c|c|c|c|c|c|c|c|c|c|c|c|c|c|c|c|c|c|}
\hline \multirow[t]{2}{*}{ Method } & \multirow{2}{*}{$\begin{array}{l}\text { Behavioral test } \\
\text { (apparatus) }\end{array}$} & \multirow{2}{*}{$\begin{array}{l}\text { Number of } \\
\text { chromosomes } \\
\text { with a QTL }\end{array}$} & \multicolumn{20}{|c|}{ Chromosomes } & \multirow[t]{2}{*}{ References } \\
\hline & & & 1 & 23 & 3 & 45 & 6 & 7 & 8 & 9 & 10 & 11 & 12 & 13 & 14 & 15 & 16 & 17 & 18 & 19 & $X$ & $\mathrm{Y}$ & \\
\hline $\mathrm{F}_{2}$ & Open field & 7 & $\mathbf{X}$ & $-X$ & $\mathbf{X}$ & - - & - & - & $\mathrm{x}$ & - & $\mathbf{X}$ & $\mathrm{x}$ & - & - & - & $\mathrm{x}$ & - & - & - & $\mathbf{X}$ & - & - & $\begin{array}{l}\text { Gershenfeld et al. } \\
\text { (1997) }\end{array}$ \\
\hline \multirow[t]{2}{*}{$\mathrm{F}_{2}$} & Light-dark box & 5 & - & - & - & -- & $\mathrm{x}$ & - & - & - & $\mathbf{X}$ & - & - & - & - & $\mathrm{x}$ & - & - & - & $\mathrm{x}$ & $\mathrm{x}$ & - & \multirow{2}{*}{$\begin{array}{l}\text { Gershenfeld and Paul } \\
\text { (1997) }\end{array}$} \\
\hline & Open field & 3 & $\mathbf{X}$ & - & - & - - & $\mathrm{x}$ & - & - & - & - & - & - & - & $\mathrm{x}$ & - & - & - & - & - & - & - & \\
\hline \multirow[t]{2}{*}{ RIS } & Light-dark box & 2 & - & - & - & - - & - & - & - & $\mathrm{x}$ & - & $\mathrm{x}$ & - & - & - & - & - & - & - & - & - & - & \multirow[t]{2}{*}{ Mathis et al. (1995) } \\
\hline & Open-field & 3 & - & $-X$ & $\mathbf{X}$ & - - & - & - & - & $\mathbf{X}$ & - & $\mathbf{X}$ & - & - & - & - & - & - & - & - & - & - & \\
\hline RIS & Open field & 8 & $\mathrm{x}$ & - & - & $\mathbf{x} \mathbf{X}$ & - & - & $\mathbf{X}$ & $\mathrm{x}$ & - & - & - & $\mathrm{x}$ & $\mathbf{X}$ & - & - & - & - & $\mathrm{x}$ & - & - & Gill and Boyle (2005) \\
\hline $\mathrm{RCS}$ & Open field & 8 & - & $-X$ & $\mathbf{X}$ & -- & $\mathbf{X}$ & - & $\mathbf{X}$ & - & - & - & - & $\mathrm{x}$ & $\mathrm{x}$ & - & - & $\mathrm{x}$ & $\mathrm{x}$ & $\mathrm{x}$ & - & - & Gill and Boyle (2005) \\
\hline \multirow[t]{2}{*}{ AIL } & Light-dark box & 2 & - & - & - & -- & - & - & - & - & $\mathbf{X}$ & - & - & - & - & - & - & - & - & $\mathbf{X}$ & - & - & \multirow[t]{2}{*}{ Zhang et al. (2005) } \\
\hline & Open field & 1 & - & - & - & -- & - & - & - & - & $\mathbf{X}$ & - & - & - & - & - & - & - & - & - & - & - & \\
\hline \multirow[t]{2}{*}{ ISCS } & Light-dark box & (1) & - & - & - & - - & - & - & - & - & $\mathbf{X}$ & - & - & - & - & - & - & - & - & - & - & - & \multirow[t]{2}{*}{ Zhang et al. (2005) } \\
\hline & Open field & (1) & - & - & - & - - & - & - & - & - & $\mathbf{X}$ & - & - & - & - & - & - & - & - & - & - & - & \\
\hline \multirow[t]{2}{*}{ CSS } & Light-dark box & 5 & $\mathbf{X}$ & - & - & $--^{\mathrm{a}}$ & $\mathbf{X}$ & - & - & $\mathbf{X}$ & - & - & - & - & - & - & - & $\mathbf{X}$ & - & $\mathbf{X}$ & - & - & \multirow[t]{2}{*}{$\begin{array}{l}\text { Singer et al. (2004, } \\
2005)\end{array}$} \\
\hline & Open field & 4 & $\mathbf{X}$ & - & - & $-{ }^{\mathrm{a}}$ & $\mathbf{X}$ & - & - & - & - & $\mathbf{X}$ & - & - & - & $\mathbf{X}$ & - & - & - & - & - & - & \\
\hline CSS & $\begin{array}{l}\text { Modified hole } \\
\text { board }\end{array}$ & 7 & - & - & - & $-x$ & - & - & $\mathrm{x}$ & - & $\mathbf{X}$ & - & - & - & - & $\mathbf{X}$ & - & - & $\mathrm{x}$ & $\mathbf{X}^{\mathrm{b}}$ & - & $\mathbf{X}$ & This article \\
\hline
\end{tabular}

$\mathbf{X}=$ significant, $\mathrm{x}=$ suggestive, and $-=$ no evidence for an anxiety QTL on a particular chromosome. ${ }^{\text {a }}$ Singer et al. (2005) did not test a complete CSS panel: CSS-5 was at the time of testing not complete. ${ }^{b}$ Based on 27 host and 27 consomic mice (see Tables 4 and 9). Abbreviations: $F_{2}=$ an $F_{2}$ intercross population, RIS = a set of recombinant inbred strains, $R C S=$ a set of recombinant congenic strains, $\mathrm{AIL}=$ an advanced intercross population, ISCS $=$ a panel of interval-specific congenic strains, $\mathrm{CSS}=\mathrm{a}$ panel of chromosome substitution strains 
Unfortunately, the rat chromosome 1 segments identified by Fernández-Teruel et al. (2002) and Terenina-Rigaldie et al. (2003) are not syntenic to mouse chromosome 19. This is an example in which comparative genomics fails to narrow the murine QTL interval (DiPetrillo et al. 2005). Furthermore, linkage for an anxiety proneness phenotype (early onset susceptibility to anxiety disorders) was suggested on the q-arm of human chromosome 10 (Smoller et al. 2001), and mouse chromosome 19 has homologous regions on human chromosomes 9, 10 and 11 (Poirier and Guénet 1998).

In summary, the present study with chromosome substitution strains suggests that mouse chromosomes 5, 8, 10, $15,18,19$, and $\mathrm{Y}$ each contain at least one QTL that is involved in anxiety-related behavior in the modified hole board. We suggest to do the consomic survey with both univariate and multivariate (bivariate) analyses and to use a two-stage approach. While others focus on chromosome 1, we have special interest for mouse chromosome 19 because of its more specific association with anxiety-related behavior. The mapping of the QTL(s) for anxiety on chromosome 19 by using an $\mathrm{F}_{2}$ intercross between CSS-19 and the C57BL/6J host strain is the subject of a subsequent study. Further experiments, including the development of (double) congenic strains or knockout strains after gene cloning, are necessary to precisely map the QTL(s) and to confirm the role of the suggested candidate genes.

Acknowledgments The authors would like to thank three anonymous reviewers for their useful comments on the manuscript.

\section{References}

Albrecht HK, Eicher EM (1997) DNA sequence analysis of Sry alleles (subgenus $\mathrm{Mus}$ ) implicates misregulation as the cause of C57BL/6J-Y ${ }^{P O S}$ sex reversal and defines the SRY functional unit. Genetics 147:1267-1277

Belknap JK (2003) Chromosome substitution strains: some quantitative considerations for genome scans and fine mapping. Mamm Genome 14:723-732

Bergeson SE, Helms ML, O’Toole LA, Jarvis MW, Hain HS, Mogil JS, Belknap JK (2001) Quantitative trait loci influencing morphine antinociception in four mapping populations. Mamm Genome 12:546-553

Bouwknecht JA, Paylor R (2002) Behavioral and physiological mouse assays for anxiety: a survey in nine mouse strains. Behav Brain Res 136:489-501

Brodkin ES, Goforth SA, Keene AH, Fossella JA, Silver LM (2002) Identification of quantitative trait loci that affect aggressive behavior in mice. J Neurosci 22:1165-1170

Coward P, Nagai K, Degao C, Thomas HD, Nagamine CM, Lau Y-FC (1994) Polymorphism of a CAG trinucleotide repeat within Sry correlates with B6.Y ${ }^{\text {dom }}$ sex reversal. Nat Genet 6:245-250

DiPetrillo K, Wang X, Stylianou IM, Paigen B (2005) Bioinformatics toolbox for narrowing rodent quantitative trait loci. Trends Genet 21:683-692
Fernández-Teruel A, Escorihuela RM, Gray JA, Aguilar R, Gil L, Giménez-Llort L, Tobeňa A, Bhomra A, Nicod A, Mott R, Driscoll P, Dawson GR, Flint J (2002) A quantitative trait locus influencing anxiety in the laboratory rat. Genome Res 12: $618-626$

Flint J, Valdar W, Shifman S, Mott R (2005) Strategies for mapping and cloning quantitative trait genes in rodents. Nat Rev Genet 6:271-286

Fullerton J (2006) New approaches to the genetic analysis of neuroticism and anxiety. Behav Genet 36:147-161

Gershenfeld HK, Paul SM (1997) Mapping quantitative trait loci for fear-like behaviors in mice. Genomics 46:1-8

Gershenfeld HK, Neumann PE, Mathis C, Crawley JN, Li X, Paul SM (1997) Mapping quantitative trait loci for open-field behavior in mice. Behav Genet 27:201-210

Gill KK, Boyle AE (2005) Quantitative trait loci for novelty/stressinduced locomotor activation in recombinant inbred (RI) and recombinant congenic (RC) strains of mice. Behav Brain Res 161:113-124

Gordon JA, Hen R (2004) Genetic approaches to the study of anxiety. Ann Rev Neurosci 27:193-122

Guillot P-V, Chapouthier G (1996) Intermale aggression and dark/ light preference in ten inbred mouse strains. Behav Brain Res 77:211-213

Kessler RC, Berglund P, Demler O, Jin R, Merinkangas KR, Walters EE (2005) Lifetime prevalence and age-of-onset distributions of DSM-IV disorders in the National Comorbidity Survey Replication. Arch Gen Psychiatry 62:593-602

Laarakker MC, Ohl F, van Lith HA (2006) Reducing the number of animals used in behavioural genetic experiments using chromosome substitution strains. Anim Welfare 15:49-54

Lim T-S, Loh W-Y (1996) A comparison of tests of equality of variances. Comput Stat Data Anal 22:287-301

Mathis C, Neumann PE, Gershenfeld H, Paul SM, Crawley JN (1995) Genetic analysis of anxiety-related behaviors and responses to benzodiazepine-related drugs in $\mathrm{AXB}$ and $\mathrm{BXA}$ recombinant inbred mouse strains. Behav Genet 25:557-568

National Research Council (2003) Guidelines for the care and use of mammals in neuroscience and behavioral research. National Academies Press, Washington

Ohl F (2003) Testing for anxiety. Clin Neurosc Res 3:233-238

Ohl F (2005) Animal models of anxiety. Handb Exp Pharmacol 169:35-69

Ohl F, Sillaber I, Binder E, Keck ME, Holsboer F (2001) Differential analysis of behavior and diazepam-induced alterations in C57BL/6N and BALB/c mice using the modified hole board test. J Psychiatr Res 35:147-154

Petrie A, Watson P (1995) Statistics for veterinary and animal science. Blackwell Science Ltd., London

Poirier C, Guénet J-L (1998) Mouse chromosome 19. Mamm Genome 8:S353-S360

Pravenec M, Kren V, Hedrich HJ, Szpirer C, Levan G, Ståhl F, St. Lezin E (1999) Report on rat chromosome 1. J Exp Amim Sci 40:5-18

Quinn GP, Keough MJ (2002) Experimental design and data analysis for biologists. Cambridge University Press, Cambridge

Roubertoux PL, Carlier M, Degrelle H, Haas-Dupertuis M-C, Phililips J, Moutier R (1994) Co-segregation of intermale aggression with the pseudoautosomal region of the $\mathrm{Y}$ chromosome in mice. Genetics 135:225-230

Sansom CE (2005) Glossary terms. In: Dunn MJ, Jorde LB, Little PFR, Subramaniam S (eds) Encyclopedia of genetics, genomics, proteomics, and bioinformatics. Wiley

Singer JB, Hill AE, Burrage LC, Olszens KR, Song J, Justice M, O'Brien WE, Conti DV, Witte JS, Lander ES, Nadeau JH (2004) 
Genetic dissection of complex traits with chromosome substitution strains of mice. Science 304:445-448

Singer JB, Hill AE, Nadeau JH, Lander ES (2005) Mapping quantitative trait loci for anxiety in chromosome substitution strains of mice. Genetics 169:855-862

Smoller JW, Acierno JS Jr, Rosenbaum JF, Biederman J, Pollack MH, Meminger S, Pava JA, Chadwick LH, White C, Bulzacchelli M, Slaugenhaupt SA (2001) Targeted genome screen of panic disorder and anxiety disorder proneness using homology to murine QTL regions. Am J Med Genet (Neuropsychiat Genet) 105:195-206

Terenina-Rigaldie E, Moisan M-P, Colas A, Beaugé F, Shah KV, Jones BC, Mormède P (2003) Genetics of behaviour: phenotype and molecular study of rats derived from high- and low-alcohol consuming lines. Pharmacogenetics 13:543-554

Trullas R, Skolnick P (1993) Differences in fear motivated behaviours among inbred mouse strains. Psychopharmacology 111:323-331
Turri MG, DeFries JC, Henderson ND, Flint J (2004) Multivariate analysis of quantitative trait loci influencing variation in anxiety-related behaviour in laboratory mice. Mamm Genome 15:69-76

Valdar W, Solberg LC, Gauguier D, Cookson WO, Rawlins JNP, Mott R, Flint J (2006) Genetic and environmental effects on complex traits in mice. Genetics 174:959-984

Willis-Owen SAG, Flint J (2006) The genetic basis of emotional behaviour in mice. Eur J Hum Genet 14:721-728

Yamasaki Y, Helou K, Watanabe TK, Sjöling A, Suziki M, Okuno S, Ono T, Takagi T, Nakamura Y, Ståhl F, Tanigami A (2001) Mouse chromosome 19 and distal rat chromosome 1: a chromosome segment in evolution. Hereditas 134:23-34

Zhang S, Lou Y, Amstein TM, Anyango M, Mohibullah N, Osoti A, Stancliffe D, King R, Iraqi F, Gershenfeld HK (2005) Fine mapping of a major locus on chromosome 10 for exploratory and fear-like behavior in mice. Mamm Genome 16:306-318 